Article

\title{
Point of Zero Charge: Role in Pyromorphite Formation and Bioaccessibility of Lead and Arsenic in Phosphate-Amended Soils
}

\author{
Ranju R. Karna ${ }^{1,2}$, Matthew R. Noerpel ${ }^{1,2}$, Todd P. Luxton ${ }^{2}\left(\mathbb{D}\right.$ and Kirk G. Scheckel ${ }^{2, *}$ \\ 1 Oak Ridge Institute for Science and Education, Oak Ridge, TN 37830, USA; karna.ranju@epa.gov (R.R.K.); \\ Noerpel.Matt@epa.gov (M.R.N.) \\ 2 United States Environmental Protection Agency, National Risk Management Research Laboratory, \\ Cincinnati, OH 45224, USA; luxton.todd@epa.gov \\ * Correspondence: Scheckel.Kirk@epa.gov; Tel.: +1-513-487-2865
}

Received: 1 March 2018; Accepted: 6 April 2018; Published: 14 April 2018

\begin{abstract}
Soluble lead $(\mathrm{Pb})$ can be immobilized in pure systems as pyromorphite through the addition of phosphorus (P) sources; however, uncertainties remain in natural systems. Knowledge of point zero charge (PZC) is important to predict the ionization of functional groups and their interaction with metal species in solution. This study utilized $\mathrm{Pb}$ - and As-contaminated soils to determine the combined effect of $\mathrm{pH}$ with respect to PZC and different rates of P-application on pyromorphite formation as well as $\mathrm{Pb}$ and arsenic (As) bioaccessibility as impacted by speciation changes. Solution chemistry analysis along with synchrotron-based $\mathrm{Pb}$ - and As-speciation as well as bioaccessibility treatment effect ratios (TERs) were conducted. Results indicated no significant effect of PZC on pyromorphite formation in P-amended soils; however, the $\mathrm{TER}_{\mathrm{Pb}}$ appeared significantly lower at $\mathrm{pH}>\mathrm{pH}_{\mathrm{PZC}}$ and higher at $\mathrm{pH}<\mathrm{pH}_{\mathrm{PZC}}(\alpha=0.05)$. In contrast, the $\mathrm{TER}_{\mathrm{As}}$ was significantly higher at $\mathrm{pH}>\mathrm{pH}_{\mathrm{PZC}}$ compared to the other two treatments for the tested soils. The lack of conversion of soil $\mathrm{Pb}$ to pyromorphite may be attributed to several reasons including the presence of highly stable minerals, such as plumbojarosite, limiting soluble $\mathrm{Pb}$ availability to react with phosphates, high $\mathrm{Fe}$ and $\mathrm{S}$ content in IKS, high organic matter in $\mathrm{BO}$, and high Ca content in NW.
\end{abstract}

Keywords: lead immobilization; pyromorphite; point zero charge; treatment effect ratio; lead speciation

\section{Introduction}

Lead is toxic to humans, especially to young children and animals [1]. Lead contamination of soil is so pervasive that excavation and subsequent back-filling with clean soil is unsustainable, very costly, and requires an impractically large volume of clean soil. Therefore, alternative approaches are required to protect the human lives that are in regular contact with $\mathrm{Pb}$-impacted soils. Alteration of $\mathrm{Pb}$ species can significantly benefit humans and environmental health by reducing its toxicity even if the total $\mathrm{Pb}$ concentration may remain the same [2,3]. Amending Pb-contaminated soils with phosphorus $(\mathrm{P})$ as an in situ remediation option has been proposed as an alternative to soil removal [4]. For the cases of $\mathrm{Pb}$-contaminated sites, evidence has shown that phosphorous $(\mathrm{P})$ compounds have been used to form highly insoluble, highly stable $\mathrm{Pb}$ precipitates that are not biologically available [5-12]. With sufficient availability of $\mathrm{P}, \mathrm{Pb}$ salts and inorganic $\mathrm{Pb}$-bearing minerals such as anglesite $\left(\mathrm{PbSO}_{4}\right)$, cerussite $\left(\mathrm{PbCO}_{3}\right)$, and galena $(\mathrm{PbS})$ spontaneously transform into pyromorphite $\left(\mathrm{Pb}_{5}\left(\mathrm{PO}_{4}\right)_{2} \mathrm{Cl}, \mathrm{OH}\right)$. Pyromorphite is several orders of magnitude less soluble than the most commonly found $\mathrm{Pb}$ minerals in soils, suggesting that the transformation of soil $\mathrm{Pb}$ to pyromorphite would reduce the bioavailability 
and therefore toxicity of $\mathrm{Pb}$. Soluble $\mathrm{Pb}$ can be immobilized in pure systems as pyromorphite by adding sources of P; however, doubts remain about the efficacy of this approach in natural soil systems $[10,11]$. The possibility of inadequate immobilization or the dissolution of pyromorphite after P-amendments have also been reported [12,13]. In general, pyromorphite formation is controlled by a soil solution $\mathrm{P}$ that is dominated by orthophosphate species which are influenced by solution $\mathrm{pH}\left(\mathrm{H}_{3} \mathrm{PO}_{4}{ }^{0} \rightarrow \mathrm{H}_{2} \mathrm{PO}_{4}{ }^{1-} \rightarrow \mathrm{HPO}_{4}{ }^{2-} \rightarrow \mathrm{PO}_{4}{ }^{3-}\right.$ as $\mathrm{pH}$ increases). Solution $\mathrm{pH}$ is directly tied to the acid dissociation constants ( $\mathrm{pKa}$ ) of phosphoric acid $\left(\mathrm{H}_{3} \mathrm{PO}_{4}{ }^{0}\right)$, indicating that at solution $\mathrm{pH}$ less than 2.12, $\mathrm{H}_{3} \mathrm{PO}_{4}{ }^{0}$ is the dominant species. Between $\mathrm{pH} 2.12$ and $7.21, \mathrm{H}_{2} \mathrm{PO}_{4}{ }^{-}$is prominent and above $\mathrm{pH} 7.21$ to $12.38, \mathrm{HPO}_{4}{ }^{2-}$ is present [9]. Thermodynamically, pyromorphite formation is favored when $\mathrm{H}_{3} \mathrm{PO}_{4}{ }^{0}$ and $\mathrm{H}_{2} \mathrm{PO}_{4}{ }^{-}$are present. Therefore, it is believed that a lower soil $\mathrm{pH}$ may need to be maintained to enhance soil $\mathrm{Pb}$ transformation to pyromorphite. Despite studies which utilized a lower soil $\mathrm{pH}$ during P-amendments, formation of pyromorphite has not been favored as expected. Likewise, the application of phosphate fertilizers in $\mathrm{Pb}$ and As co-contaminated soil has been correlated with increased As mobility [14,15] due to sorption site competition between arsenate $\left(\mathrm{AsO}_{4}{ }^{3-}\right)$ and phosphate $\left(\mathrm{PO}_{4}{ }^{3-}\right)$. Care should be taken when considering phosphate amendments to sequester $\mathrm{Pb}$ as other elements may become more mobile and result in adverse effects.

Consideration of native soil $\mathrm{pH}$, organic matter content, and water holding capacity have been explored, but little has been examined on external controls to alter the soil environment prior to phosphate amendments. The $\mathrm{pH}$ at which the sorbent surface charge assumes a zero value is defined as the point of zero charge $\left(\mathrm{pH}_{\mathrm{PZC}}\right)$. At this $\mathrm{pH}$, the sum charge of the positive surface sites is equal to that of the negative ones resulting in a high state of entropy and disequilibrium. The knowledge of $\mathrm{pH}_{\mathrm{PZC}}$ helps to hypothesize on the ionization of functional groups and their interaction with metal species in solution. At solution $\mathrm{pHs}$ higher than $\mathrm{pH}_{\mathrm{PZC}}$, sorbent surface is negatively charged and can interact with positively charged metal species. However, at $\mathrm{pHs}$ lower than $\mathrm{pH}_{\mathrm{PZC}}$, solid surface is positively charged and can interact with negative species [16]. We theorized that driving the $\mathrm{pH}$ of a soil system to a state of disequilibrium may enhance contaminant immobilization.

Potentiometric titration method is more commonly used in soils having surfaces dominated by variable charge colloids. Point zero salt effect, defined as a distinct point $(\mathrm{pH})$ at the intersection of titration curves generated for different concentrations of non-specifically adsorbing electrolytes, was measured for all the tested soils in this study. A detailed review and discussion of surface charging as well as the various points of zero charge are described in previous literature [17-19].

An essential aspect of in situ immobilization of $\mathrm{Pb}$ via phosphate amendments is to lower the risk (bioavailability) of $\mathrm{Pb}$ in soil. Bioavailability can be assessed with animal (in vivo) and simple chemical extraction assays (in vitro). As stated in EPA Method 1340, the assay at $\mathrm{pH} 1.5$ is not suitable for phosphate-amended soils which overestimates $\mathrm{Pb}$ bioaccessibility in amended soils. The difference in $\mathrm{Pb}$ extractability at $\mathrm{pH} 1.5$ versus $\mathrm{pH} 2.5$ for phosphate-amended soils may be a result of a change in phosphate chemistry. Below pH 2.12, phosphate prefers to be $\mathrm{H}_{3} \mathrm{PO}_{4}$; above $\mathrm{pH} 2.12$, phosphate prefers $\mathrm{H}_{2} \mathrm{PO}_{4}{ }^{-1}$. A slight shift in extraction $\mathrm{pH}$ can have a profound effect on phosphate chemistry and extractability. Therefore, in vitro bioaccessibility assay (IVBA) extraction at both $\mathrm{pH} 1.5$ and $\mathrm{pH}$ 2.5 following the standard IVBA procedure was conducted in the present study.

Any amendment is expected to alter the chemistry of metals present in soils and these changes should be measured and evaluated. Metal speciation identifies the changes in mineralogy and strongly determines the bioavailability on the basis of differences in the solubility of soil minerals [20,21]. Additional details on the advantages and successes of using synchrotron-based techniques in contaminated soils can be found in past studies [3,22-25], especially for speciation and quantification $\mathrm{Pb}$ in P-amended soils.

The objective of this study was a comparison of the combined effects of $\mathrm{pH}$ with respect to PZC, an analysis of different rates of phosphate application on the formation and stability of pyromorphite over time, as well as how speciation changes have impacted $\mathrm{Pb}$ and As bioaccessibility. Attempts 
have been made to fine-tune and understand the limitations of $\mathrm{Pb}$ conversion to pyromorphite in phosphate-amended soils.

\section{Materials and Methods}

\subsection{Soil Characterization}

This study evaluated soils contaminated with $\mathrm{Pb}$ and As such as BO (Orchard, NC, USA), IKS (mining-impacted, Dewey-Humboldt, AZ, USA), and NW (smelter-impacted, Lincoln, NE, USA). $\mathrm{BO}$ and IKS soils have been evaluated in previous studies for $\mathrm{Pb}$ and As bioaccessibility [26] and NW soil provided an opportunity to investigate $\mathrm{Pb}$ immobilization at a Superfund site. $\mathrm{BO}$ was collected from Haywood country in North Carolina where an orchard was in use from 1908 to 1988; during this time, a lead-arsenate pesticide was heavily used and, accordingly, the site is highly contaminated with $\mathrm{Pb}$ and As. All the tested soils were classified at county level using the NRCS-USDA soil classification database available online. BO was classified as fine-loamy, mixed, superactive, mesic Humic Hapludults. IKS soil was mining-impacted soil collected from Yavapai county, Arizona with very high Fe ( 15\%) and S ( 8\%), and about $2 \%$ organic matter content.

IKS was classified as fine-loamy, mixed, mesic Ustollic Haplargids. NW was collected from urban Lincoln, Nebraska and exhibited total Pb (1730 mg kg$\left.{ }^{-1}\right)$, As $\left(9 \mathrm{mg} \mathrm{kg}^{-1}\right), \mathrm{Mn}\left(517 \mathrm{mg} \mathrm{kg}^{-1}\right)$, and Fe $(2.5 \%)$. NW was classified as fine-silty, mixed, mesic Cumulic Hapludolls. All the tested soils were oven-dried and properly homogenized using sample splitter (\# 1613, Carpco Inc., Texarkana, AR, USA) [27].

\subsection{Physicochemical Characterization}

The homogenized soil in triplicate were subjected to measure soil $\mathrm{pH}$ in water after being sieved and oven-dried. Total extractable solid digestion (US EPA Method 3051a) [28] was conducted on each soil to measure the total contents of $\mathrm{Pb}, \mathrm{As}, \mathrm{Mg}, \mathrm{Ca}, \mathrm{Fe}, \mathrm{P}$, and most of the transition metals by using inductively coupled plasma-optical emission spectroscopy (ICP-OES, ICP-6500 Trace Analyzer, Thermo Scientific, Waltham, MA, USA). Certified standard reference material (NIST 2710A) was digested and analyzed along with the samples with an acceptance range of $\pm 10 \%$ of the certified value to verify the precision and accuracy in sample preparation and analysis. Total $\mathrm{Pb}$ and As concentrations were determined for BO $\left(2065,308 \mathrm{mg} \mathrm{kg}^{-1}\right)$, NW $\left(1730,19 \mathrm{mg} \mathrm{kg}^{-1}\right)$, and IKS $\left(2462,3958 \mathrm{mg} \mathrm{kg}^{-1}\right)$ $(n=4)$, respectively (Table 1$)$.

Table 1. Total element contents of IKS (IKJ 583), NW soils, and BO determined in $<250 \mu \mathrm{m}$ size by using microwave-assisted acid digestion (EPA 3051A).

\begin{tabular}{cccc}
\hline Soil Label & IKS & NW & BO \\
\hline Source & $\begin{array}{c}\text { Mining Slag } \\
\left(\mathbf{m g ~ k g}^{-1}\right)\end{array}$ & $\begin{array}{c}\text { Smelter Impacted } \\
\mathbf{( m g ~ k g}^{-1} \mathbf{)}\end{array}$ & $\begin{array}{c}\text { Pesticide } \\
\text { Spray Lead Arsenate } \\
\left(\mathbf{m g ~ k}^{-\mathbf{1}} \mathbf{)}\right.\end{array}$ \\
\hline $\mathrm{Al}$ & 11,378 & 15,653 & 42,342 \\
$\mathrm{As}$ & 3958 & 19 & 308 \\
$\mathrm{Ca}$ & 26,648 & 14,453 & 5275 \\
$\mathrm{Cd}$ & 9 & 6 & 0.1 \\
$\mathrm{Co}$ & 10 & 10 & 19 \\
$\mathrm{Cr}$ & $<\mathrm{DL}$ & 26 & 106 \\
$\mathrm{Cu}$ & 327 & 513 & 212 \\
$\mathrm{Fe}$ & 138,400 & 25,010 & 38,874 \\
$\mathrm{Mg}$ & 9074 & 3431 & 11,405 \\
$\mathrm{Mn}$ & 408 & 517 & 1590 \\
$\mathrm{P}$ & 952 & 1354 & 1472 \\
$\mathrm{~Pb}$ & 2462 & 1730 & 2065 \\
$\mathrm{Zn}$ & 4195 & 2141 & 180 \\
$\mathrm{~S}$ & 85,864 & 1582 & 858 \\
\hline
\end{tabular}


Overall, IKS was high in Fe and S, NW had slightly elevated Ca levels compared to other elemental contents, whereas $\mathrm{BO}$ had very high organic matter content $(\sim 7.2 \%)$.

The point zero charge (PZC) was determined by following Sparks [29]. The selection of those specific $\mathrm{pHs}$ below and above $\mathrm{pH}_{\mathrm{PZC}}$ were done based on the understanding of relationships and physiochemical interactions of different $\mathrm{P}$ species in soils at varying $\mathrm{pHs}$.

\subsection{Batch Experiment Setup and Sample Collection}

The batch experiment for BO was modified into a short-term preliminary study prior to conducting any long-term batch experiment. The results obtained from this study exhibited no pyromorphite formation, possibly a result of the presence of high Fe oxides and high organic matter. Instead, IKS and NW soils were used for long-term batch experiment to provide a more controlled environment to determine the role of PZC in pyromorphite formation.

Each treatment combination had three replicates for IKS and NW, with only one for BO (preliminary experiment). About $800 \mathrm{~mL}$ of $0.01 \mathrm{M} \mathrm{CaCl}_{2}$ solution was added to $1000 \mathrm{~mL}$ HDPE bottle with HDPE plastic caps which contained pre-weighed $16 \mathrm{~g}$ of soil $(20 \mathrm{~g} / \mathrm{L})$. The required amount of phosphoric acid $\left(\mathrm{H}_{3} \mathrm{PO}_{4}\right)$ was used to treat the samples at different levels of P-amendment. The desired $\mathrm{pH}$ range was maintained at those particular pHs using Metler Toledo DL-50 Graphix via acid-base titration for the first three days. Once the samples were $\mathrm{pH}$-adjusted, the bottles were loaded onto a tumbler to keep them mixed continuously. The $\mathrm{pHs}$ of solution matrix were monitored every $24 \mathrm{~h}$ for the first two weeks, every three days for a month, and every week until $\mathrm{pHs}$ were stabilized.

The incubated bottles were periodically sub-sampled at 1-day, 1-week, 1-month, 3-month, and 6-month periods for about $50 \mathrm{~mL}$ of suspension. While pipetting, the suspension was continuously stirred for homogeneous sampling. The solid and liquid phases were separated by centrifuging at $4000 \mathrm{rpm}$ for $10 \mathrm{~min}$. Aqueous samples collected from the batch experiment were filtered through $0.45 \mu \mathrm{m}$ filters and separated into aliquots for both total dissolved elements and anions measurements and stored as required until analyzed by ICP-OES and ion chromatography (ICS 5000, Thermo Scientific, Waltham, MA, USA). The bulk soil samples obtained after centrifugation were frozen until freeze-dried for X-ray absorption spectroscopy (XAS) and in vitro bioaccessibility analyses.

\subsection{Assessment of $\mathrm{Pb}$ and As Bioaccessibility}

US EPA Method 1340 at $\mathrm{pH} 1.5$ was used for an in vitro bioaccessibility test. A similar procedure was used for bioaccessibility assays conducted at $\mathrm{pH} 2.5$ as the only alteration. The treatment efficacy was expressed as the ratio of the $\mathrm{Pb}$ bioaccessibility in the treated soil divided by the $\mathrm{Pb}$ bioaccessibility in the untreated soil (treatment effect ratio (TER)). Studies have reported TER range from P-treated soils as a minimum of 0.08 [5] to maximum of 1.16 [30] with a median value of 0.78 . A TER value of one indicates that the treatment had no effect on $\mathrm{Pb}$ bioaccessibility; a TER value of $<1$ indicates a decrease in $\mathrm{Pb}$ bioaccessibility due to treatment effect [31]. Median TER results indicated that P-amendments reduced $\mathrm{Pb}$ bioaccessibility but not significantly $[5,30]$.

\subsection{Quality Assurance and Quality Control (QA/QC) Checks}

The accuracy of EPA Method 3051A digestion method was confirmed by a quantitative average of $\mathrm{Pb}$ recovery from NIST 2710A. During the determination of the Pb concentration in soil digests, triplicate analysis, spiked sample recoveries, and check values were included. In vitro bioaccessibility assessment included all the QA/QC checks as mentioned in the EPA method 1340. Details on QA/QC checks are provided in Table S1A,B.

\subsection{XAS Data Collection and Analyses}

X-ray absorption spectroscopy (XAS) was performed on all the treatment combinations in order to understand the $\mathrm{Pb}$ and As chemistry with different rates of $\mathrm{P}$-amendment at different $\mathrm{pH}$ values at the Materials Research Collaborative Access Team (MRCAT) 10-ID for Pb [32] and 10-BM for 
As [33] beamlines, Advanced Photon Source (Argonne National Laboratory, Lemont, IL, USA). For XAS data collection, the individual soil sample fractions ( 100 mg) were mixed with $10 \mathrm{mg}$ of polyvinylpyrrolidone (PVP) gently ground with an agate mortar and pestle to homogenize, pressed into a 1-cm pellet, and mounted onto Kapton tape. An integrated approach of solution chemistry analysis, XAS analysis, along with bioaccessibility assessments were conducted in order to meet the study objectives.

\subsection{Statistical Analysis}

To evaluate the broader trends across the three soils investigated, one- and two-way ANOVA tests were performed with a posthoc Tukey's means comparison. TER-As were normally distributed; however, the TER-Pb values were transformed by taking the square root of the value to achieve a normalized distribution of values. All analyses were performed in OriginPro 2015.

\section{Results and Discussions}

\subsection{Effect of P-Amendment on Soil $p H$}

When phosphoric acid (PA) was added to the soil suspensions, its influence on $\mathrm{pH}$ was variable depending on the buffering capacity of each individual soil. Soil $\mathrm{pH}\left(0.01 \mathrm{M} \mathrm{CaCl}_{2}\right)$ in IKS decreased from 3.66 to $2.84(1 \% \mathrm{PA}), 2.29(5 \% \mathrm{PA})$, and $2.07(10 \% \mathrm{PA})$. Soil $\mathrm{pH}\left(0.01 \mathrm{M} \mathrm{CaCl}_{2}\right)$ in NW decreased from 6.98 to $5.22(1 \% \mathrm{PA}), 3.25$ (5\% PA), and $2.29(10 \% \mathrm{PA})$. Soil $\mathrm{pH}\left(0.01 \mathrm{M} \mathrm{CaCl}_{2}\right)$ in BO decreased from 5.60 to 4.05 ( $1 \% \mathrm{PA}), 3.03$ (5\% PA), and 2.68 (10\% PA). The highest buffering of $\mathrm{pH}$ was observed in $\mathrm{BO}$ due to the presence of high organic matter content. However, the desired $\mathrm{pHs}$ were maintained by adding potassium hydroxide $(\mathrm{KOH})$ and hydrochloric acid $(\mathrm{HCl})$ as required.

\subsection{Pre-Amendment XAS-Based Pb-and As-Mineralogy in Tested Soils}

The primary $\mathrm{Pb}$ mineral composition in pre-amended IKS included plumbojarosite $\left(\mathrm{Pb}_{0.5} \mathrm{Fe}_{3}\left(\mathrm{SO}_{4}\right)_{2}(\mathrm{OH})_{6}\right)$ and $\mathrm{Pb}$ sorbed to iron oxides. The other minor $\mathrm{Pb}$ minerals included $\mathrm{Pb}$-phosphates and magnetoplumbite $\left[\mathrm{Pb}\left(\mathrm{Fe}^{3+}, \mathrm{Mn}^{3+}\right)_{12} \mathrm{O}_{19}\right]$. Lead bound to $\mathrm{Fe}$ (hydr)oxides was very common in a wide variety of environments in the presence of high Fe [34]. On the other hand, As in IKS was primarily associated with the weathering products of arsenic sulfide such as jarosite (52-70\%), scorodite (hydrous ferrous arsenate) (31-38\%), and $\mathrm{As}(\mathrm{V})$ ions sorbed on goethite (14-18\%). Incorporation of $\mathrm{As}(\mathrm{V})$ in jarosite derived from the weathering of As-rich pyrite is well documented $[35,36]$.

Lead-XAS data analysis on $\mathrm{BO}$, which was contaminated with lead-arsenate $\left(\mathrm{PbHAsO}_{4}\right)$ pesticide, indicated $\mathrm{Pb}$ species mostly as sorbed phases to $\mathrm{Fe}$ (hydr)oxides and $\mathrm{Pb}$ complexed with humic acids as the minor component, which was expected in soil with high organic matter and high iron oxides. Arsenic speciation in $\mathrm{BO}$ included $\mathrm{As}(\mathrm{V})$ ions sorbed to birnessite $(65-69 \%)$ and $\mathrm{Pb}-\mathrm{As}$ pesticide (31-36\%). More details on an initial mineralogy of IKS and BO can be referred to in R.R. Karna et al. [26]. Lead-XAS data analysis in NW indicated $\mathrm{Pb}$ bound to humic acids $(75 \%)$ as the primarily dominant mineral; other minor minerals identified were anglesite $(14 \%)$ and $\mathrm{Pb}$ sorbed to ferrihydrite $(11 \%)$. Arsenic speciation in NW detected As(V) sorbed to goethite (28\%), arsenopyrite (21\%), As(V) sorbed to birnessite $(20 \%), \mathrm{As}(\mathrm{V})$ incorporated into jarosite $(18 \%)$, and scorodite $(13 \%)$.

\subsection{Effect of P-Amendment and Different $p H s$ on Pb-and As-Chemistry in Tested Soils}

\subsubsection{IKS (IKJ 583)}

The ICP-OES analysis conducted on the effluent samples revealed no significant difference in total dissolved $\mathrm{Pb}$ in P-amended compared to non-amended treatments in IKS (Table S2), possibly a result of the lower solubility of $\mathrm{Pb}$ in soils. Interestingly, total dissolved As concentrations were lowest in the low $\mathrm{P}$-amended treatments set at $>\mathrm{pH}_{\mathrm{PZC}}$ indicating that the $\mathrm{pH}$ effect was more predominant 
at low P-application in reducing the total dissolved As concentration in effluent samples. Decreasing soluble As concentration along with a decreasing soluble Ca concentration at $>\mathrm{pH}_{\mathrm{PZC}}(\mathrm{pH}$ of 7$)$ with medium and high $\mathrm{P}$ indicates higher possibilities of calcium arsenate formation which is more stable towards neutral $\mathrm{pH}$, as reported by Bothe et al. [37]. Regarding the non-amended positive control (POS_CTRL), As solubility remained low and no $\mathrm{pH}$ effect was observed. However, high P-amendment demonstrated As mobilization, especially at $\mathrm{pH}_{\mathrm{PZC}}(\mathrm{pH}$ of 4$)$ and $<\mathrm{pH}_{\mathrm{PZC}}(\mathrm{pH}$ of 3$)$. This observation may be self-evident because of the known effect of competitive adsorption mechanism between arsenate and phosphate that have similar deprotonation constants in solution and may have similar effects on the surface charge of the solid [38-42].

Considering initial $\mathrm{Pb}$ mineralogy, there were no significant changes in $\mathrm{Pb}$ species upon different rate of P-amendment in IKS at $\mathrm{pH}_{\mathrm{PZC}}(\mathrm{pH}$ of 4$),>\mathrm{pH}_{\mathrm{PZC}}(\mathrm{pH}$ of 7$)$, and $<\mathrm{pH}_{\mathrm{PZC}}(\mathrm{pH}$ of 3$)$. Plumbojarosite $\left(\mathrm{Pb}_{0.5} \mathrm{Fe}_{3}\left(\mathrm{SO}_{4}\right)_{2}(\mathrm{OH})_{6}\right)$ remained the primary geochemical phase across the treatment combinations. Other minor minerals included $\mathrm{Pb}$ sorbed to iron (hydr)oxides, lead phosphates $\left(\mathrm{Pb}_{3}\left(\mathrm{PO}_{4}\right)_{2}\right)$, hydroxypyromorphite $\left(\mathrm{Pb}_{5}\left(\mathrm{PO}_{4}\right)_{3} \mathrm{OH}\right)$, and anglesite $\left(\mathrm{PbSO}_{4}\right)$. No particular trend in $\mathrm{Pb}$-phosphate formations at $>\mathrm{pH}_{\mathrm{PZC}}$ was observed despite total soluble $\mathrm{P}$ displayed significant reduction at $>\mathrm{pH}_{\mathrm{PZC}}$. This indicates the possibility of insoluble calcium phosphate formation with the observed reduction in Ca-concentration at $>\mathrm{pH}_{\mathrm{PZC}}$ (Figure 1). Reduction in total soluble $\mathrm{P}$ at $>\mathrm{pH}_{\mathrm{PZC}}$ was also supported by the phosphate measurement in IKS (Table S5). Solubility of primary mineral phases of $\mathrm{Pb}$ and their reaction products with phosphate was very significant in determining the $\mathrm{P}$-based remediation of $\mathrm{Pb}$ in contaminated soils [41]. For example, if the contaminated soils had more stable forms of $\mathrm{Pb}$, dissolution rates for $\mathrm{Pb}$ were much slower. Studies have reported pyromorphite formation in the presence of different lead minerals and revealed that low $\mathrm{pH}(\leq 4)$ is favorable for cerussite dissolution and its conversion to pyromorphite [11]. High $\mathrm{pH}(>5)$ is favorable for dissolution of galena $(\mathrm{PbS})$ and transformation of galena to pyromorphite [43]. Therefore, solubility of primary $\mathrm{Pb}$ solid phases and their reaction with phosphate cannot be neglected when assessing the efficiency of P-induced immobilization of soils [41]. However, for the IKS soil, Pb-mineralogy remained largely similar to the presence of plumbojarosite as a dominant mineral, despite the long (180-day) incubation.

Hindered dissolution of plumbojarosite in IKS may not have provided enough soluble $\mathrm{Pb}$ to react with phosphates for pyromorphite formation even after high P-amendment was applied at variable $\mathrm{pHs}$. Despite the lack of pyromorphite formation, the bioaccessibility measurements for $\mathrm{Pb}$ indicated lower TERs estimations ( 0.16 to 0.52 via IVBA conducted at $\mathrm{pH} 2.5$ ) in all the low, medium, and high P-amended treatments set at $>\mathrm{pH}_{\mathrm{PZC}}$ (Table 2).

Arsenic speciation in the original IKS was primarily associated with the weathering products of arsenic minerals, such as As_jarosite (52-70\%), scorodite (hydrous ferrous arsenate) (31-38\%), and $\mathrm{As}(\mathrm{V})$ ions sorbed on goethite (14-18\%) [26]. Considering an initial As mineralogy, there were no significant changes in As-speciation upon different rates of P-amendment in IKS at $\mathrm{pH}_{\mathrm{PZC}}$ ( $\mathrm{pH}$ of 4 ), $>\mathrm{pH}_{\mathrm{PZC}}(\mathrm{pH}$ of 7 ), and $<\mathrm{pH}$ PZC ( $\mathrm{pH}$ of 3). However, As_jarosite was decreased to $<20 \%$ and $\mathrm{As}(\mathrm{V})$ sorbed to goethite was increased to $32-47 \%$, scorodite remained almost constant (Figure 2). The observed substantial repartitioning of As to the surface complexed fraction from its initially coprecipitated form (As_jarosite) indicates that $\mathrm{As}(\mathrm{V})$ in the current study was partially controlled by slow redox kinetics resulting in the $\mathrm{Fe}^{2+}$-induced transformation of jarosite. Concurrently, it also led to the acceleration of the structural transformation of metastable $\mathrm{Fe}(\mathrm{III})$ minerals to subsequent precipitation of more stable phases, such as goethite, within $24 \mathrm{~h}$ in the presence of high Fe concentration. These results are also supported by previous studies [44-46]. The $\mathrm{Fe}^{2+}$-induced transformation to $\mathrm{Fe}(\mathrm{III})$ oxides can enhance or impede mobilization and bioavailability of As [47]. Overall, there was a decrease in As_jarosite content by 32 to $44 \%$, whereas increases in scorodite by approximately $10 \%$ and As_goethite formation by $28 \%$ were observed (Figure 2).

However, TERs estimations for As were lowest ( 0.41 at $\mathrm{pH} 1.5$ and 0.68 at $\mathrm{pH} 2.5$ ) for the treatments set at $<\mathrm{pH}_{\mathrm{PZC}}$, and, interestingly with high P-amendment despite similar As mineralogy across the treatment combinations (Table 2). 
a.

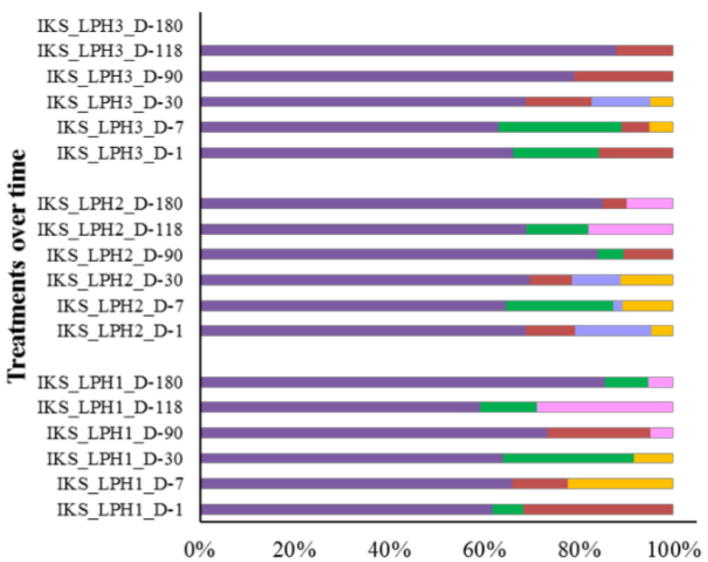

c.

- Plumboyarosite $\quad$ Lead phosphate

$\because \mathrm{Pb}$ ferrihydrite $\quad$ Plumboferrite

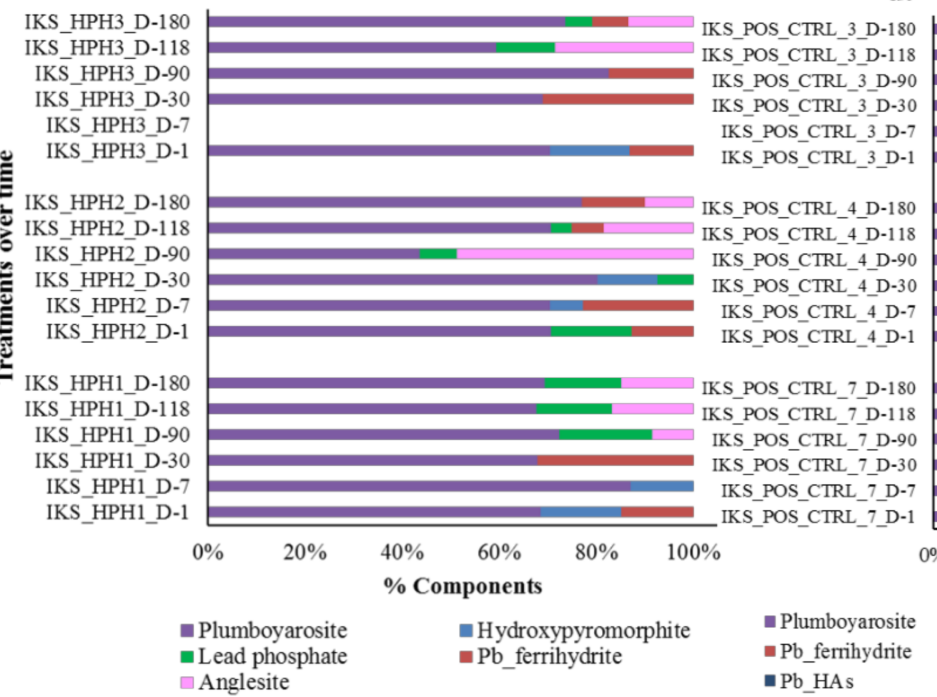

b.

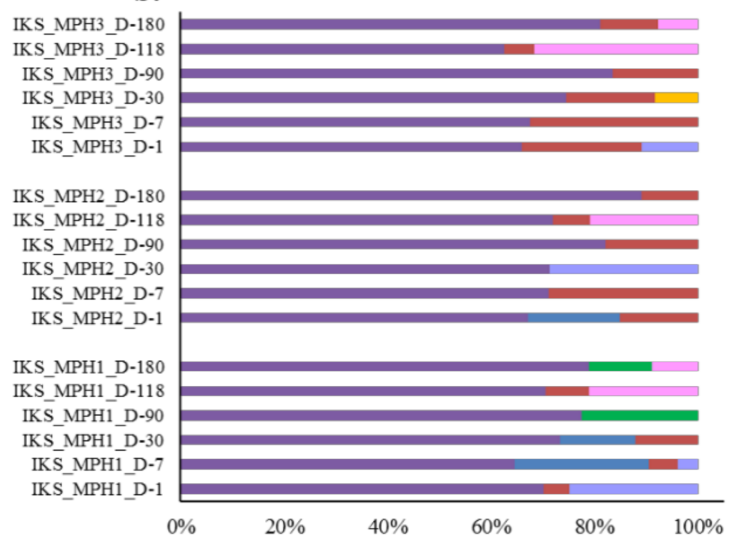

$\because$ Plumboyarosite $\quad$ Hydroxypyromorphite $\quad$ Lead phosphate $\because \mathrm{Pb}$ ferrihydrite $\quad$ Plumboferrite $\quad \square$ Anglesite $\square$ Pb Hydroxyapatite

d.

Figure 1. Bar chart represents the bulk $\mathrm{Pb}$-X-ray absorption spectroscopy (XAS) results obtained via statistical analyses; principal component analysis (PCA), and linear combination fitting (LCF) results showing \% components of Pb minerals in (a) Low P-amended (1\%); (b) Medium P-amended (5\%); (c) High P-amended (10\%); (d) Non-amended positive control for IKS at $\mathrm{pH}_{\mathrm{PZC}}(\mathrm{pH} 4),>\mathrm{pH}_{\mathrm{PZC}}$ ( $\mathrm{pH} 7$ ), and $<\mathrm{pH}_{\mathrm{PZC}}(\mathrm{pH} 3)$ for 1-, 7-, 30-, 90-, 118-, and 180-day of incubation. IKS in the label represents IKJ 583, "L" stands for low P-amendment, " $\mathrm{M}$ " for medium P-amendment, and " $\mathrm{H}^{\text {" for }}$ high $\mathrm{P}$-amendment. "PH1" in the samples label represents $>\mathrm{pH}_{\mathrm{PZC}}$, "PH2" represents $\mathrm{pH}_{\mathrm{PZC}}$, and "PH3" represents $<\mathrm{pH}_{\mathrm{PZC}}$. "POS_CTRL" stands for positive control. "D" represents for the days of incubation. "HAs" in the label represents humic acids. 
Table 2. Treatment effect ratio (TER) for bioaccessible lead measurement at $\mathrm{pH} 1.5$ and $\mathrm{pH} 2.5$ for IKS (IKJ 583).

\begin{tabular}{|c|c|c|c|c|c|c|c|c|c|c|c|c|}
\hline \multirow[b]{2}{*}{ Lead } & \multicolumn{6}{|c|}{ pH 1.5} & \multicolumn{6}{|c|}{ pH 2.5} \\
\hline & $\begin{array}{c}\text { Day } \\
1\end{array}$ & $\begin{array}{c}\text { Day } \\
7\end{array}$ & $\begin{array}{c}\text { Day } \\
30\end{array}$ & $\begin{array}{c}\text { Day } \\
90\end{array}$ & $\begin{array}{c}\text { Day } \\
118\end{array}$ & $\begin{array}{c}\text { Day } \\
180\end{array}$ & $\begin{array}{c}\text { Day } \\
1\end{array}$ & $\begin{array}{c}\text { Day } \\
7\end{array}$ & $\begin{array}{c}\text { Day } \\
30\end{array}$ & $\begin{array}{c}\text { Day } \\
90\end{array}$ & $\begin{array}{c}\text { Day } \\
118\end{array}$ & $\begin{array}{c}\text { Day } \\
180\end{array}$ \\
\hline Treatment & TER & TER & TER & TER & TER & TER & TER & TER & TER & TER & TER & TER \\
\hline IKS_LPH1 > PZC (7.0) & 0.34 & 0.29 & 0.39 & 0.49 & 0.57 & 0.71 & 0.17 & 0.21 & 0.25 & 0.35 & 0.34 & 0.37 \\
\hline IKS_LPH2 PZC (4.0) & 0.72 & 0.79 & 0.97 & 2.38 & 2.26 & 0.99 & 0.44 & 0.49 & 0.68 & 0.69 & 1.76 & 0.53 \\
\hline IKS_LPH3 < PZC (3.0) & 0.86 & 2.17 & 1.96 & 1.55 & 1.46 & 1.13 & 0.65 & 0.59 & 1.75 & 0.7 & 1.69 & 0.41 \\
\hline IKS_MPH1 > PZC (7.0) & 0.35 & 0.34 & 0.38 & 0.41 & 0.41 & 0.72 & 0.17 & 0.19 & 0.18 & 0.16 & 0.16 & 0.48 \\
\hline IKS_MPH2 PZC (4.0) & 0.91 & 0.94 & 1.08 & 2.15 & 2.66 & 1.58 & 0.58 & 0.76 & 0.62 & 1.39 & 2.26 & 0.53 \\
\hline IKS_MPH3 < PZC (3.0) & 1.04 & 2.63 & 2.25 & 1.74 & 1.65 & 2.00 & 1.00 & 0.94 & 1.74 & 1.48 & 1.5 & 1.14 \\
\hline IKS_HPH1 > PZC (7.0) & 0.38 & 0.40 & 0.37 & 0.39 & 0.40 & 0.56 & 0.17 & 0.21 & 0.23 & 0.24 & 0.19 & 0.52 \\
\hline IKS_HPH2 PZC (4.0) & 1.05 & 1.04 & 1.19 & 2.66 & 2.49 & 1.74 & 0.60 & 0.75 & 0.46 & 1.02 & 1.44 & 0.85 \\
\hline IKS_HPH3 < PZC (3.0) & 1.16 & 3.28 & 2.11 & 3.60 & 1.82 & 1.80 & 1.06 & 0.74 & 1.53 & 2.46 & 1.82 & 0.46 \\
\hline \multirow[b]{2}{*}{ Arsenic } & \multicolumn{6}{|c|}{ pH 1.5} & \multicolumn{6}{|c|}{$\mathrm{pH} 2.5$} \\
\hline & $\begin{array}{c}\text { Day } \\
1\end{array}$ & $\begin{array}{c}\text { Day } \\
7\end{array}$ & $\begin{array}{c}\text { Day } \\
30\end{array}$ & $\begin{array}{c}\text { Day } \\
90\end{array}$ & $\begin{array}{c}\text { Day } \\
118\end{array}$ & $\begin{array}{c}\text { Day } \\
180\end{array}$ & $\begin{array}{c}\text { Day } \\
1\end{array}$ & $\begin{array}{c}\text { Day } \\
7\end{array}$ & $\begin{array}{c}\text { Day } \\
30\end{array}$ & $\begin{array}{c}\text { Day } \\
90\end{array}$ & $\begin{array}{c}\text { Day } \\
118\end{array}$ & $\begin{array}{c}\text { Day } \\
180\end{array}$ \\
\hline Treatment & TER & TER & TER & TER & TER & TER & TER & TER & TER & TER & TER & TER \\
\hline IKS_LPH1 > PZC (7.0) & 1.51 & 1.65 & 1.80 & 1.58 & 1.84 & 2.07 & 3.68 & 4.53 & 4.93 & 2.86 & 3.95 & 4.65 \\
\hline IKS_LPH2 PZC (4.0) & 1.14 & 1.25 & 1.50 & 1.14 & 1.34 & 1.57 & 2.22 & 2.48 & 2.88 & 1.73 & 2.99 & 2.48 \\
\hline IKS_LPH3 < PZC (3.0) & 0.93 & 0.91 & 1.08 & 1.10 & 1.13 & 1.35 & 2.01 & 2.09 & 2.18 & 1.94 & 2.20 & 2.01 \\
\hline IKS_MPH1 > PZC (7.0) & 0.70 & 1.98 & 2.45 & 1.84 & 1.34 & 2.28 & 5.34 & 7.92 & 10.89 & 5.19 & 8.29 & 8.01 \\
\hline IKS_MPH2 PZC (4.0) & 0.93 & 0.93 & 0.94 & 0.50 & 1.04 & 0.95 & 1.53 & 1.42 & 1.30 & 1.06 & 1.73 & 1.23 \\
\hline IKS_MPH3 < PZC (3.0) & 0.75 & 0.64 & 0.57 & 0.60 & 0.63 & 0.62 & 0.93 & 1.11 & 0.86 & 0.79 & 0.94 & 0.85 \\
\hline IKS_HPH1 > PZC (7.0) & 1.52 & 1.79 & 2.22 & 1.83 & 2.16 & 2.31 & 4.94 & 7.14 & 9.66 & 5.09 & 7.50 & 8.55 \\
\hline IKS_HPH2 PZC (4.0) & 0.81 & 0.80 & 0.69 & 0.79 & 0.74 & 0.69 & 2.01 & 1.13 & 0.86 & 0.76 & 1.22 & 0.89 \\
\hline IKS_HPH3 < PZC (3.0) & 0.68 & 0.55 & 0.41 & 0.46 & 0.46 & 0.41 & 1.35 & 0.84 & 0.56 & 0.58 & 0.73 & 0.68 \\
\hline
\end{tabular}

Treatment effect ratio (TER) represents the bioaccessibility in amended soil divided by bioaccessibility in the untreated soil at that particular $\mathrm{pH}$. IKS in the label represents IKJ 583, "L" stands for low P-amendment, " $\mathrm{M}$ " for medium P-amendment, and " $\mathrm{H}$ " for high P-amendment. "PH1" in the samples label represents $>\mathrm{pH}_{\mathrm{PZC}}(\mathrm{pH} 7)$ "PH2" represents $\mathrm{pH}_{\mathrm{PZC}}(\mathrm{pH} 4)$, and "PH3" represents $<\mathrm{pH}_{\mathrm{PZC}}(\mathrm{pH} 3)$.

a.

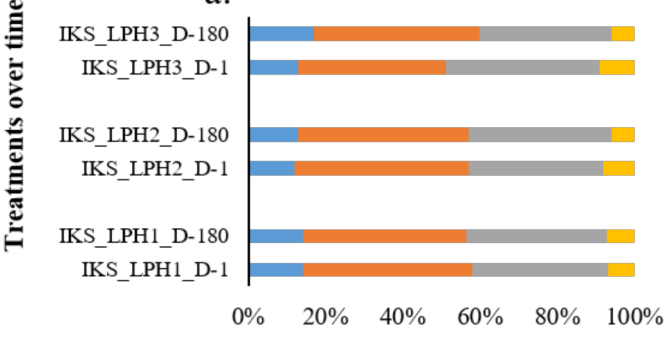

C.

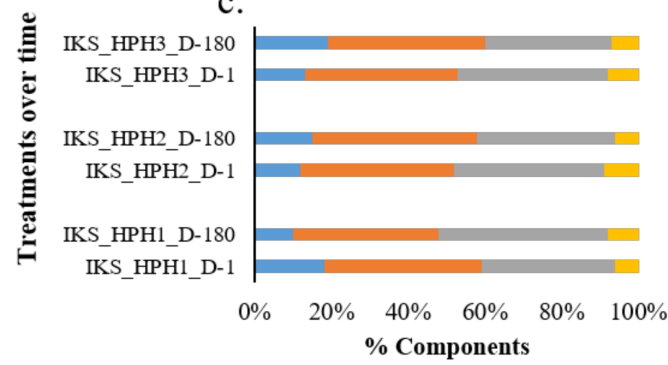

as_Jarosite $₫$ Scorodite $\square$ As_Goethite $\square$ As_Haematite b.

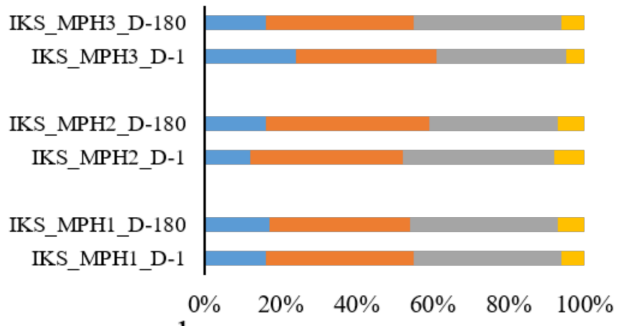

d.

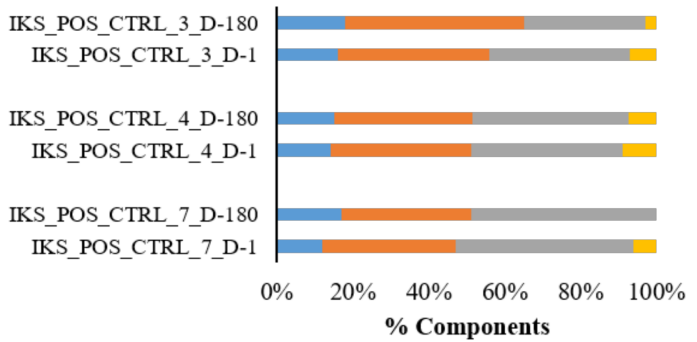

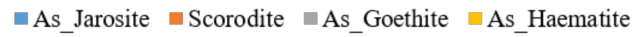

Figure 2. Bar chart represents the bulk As-XAS results obtained via statistical analyses; principal component analysis (PCA), and linear combination fitting (LCF) showing \% components of $\mathrm{Pb}$-minerals in (a) Low P-amended (1\%); (b) Medium P-amended (5\%); (c) High P-amended (10\%); (d) Non-amended positive control for IKJ 583 at $\mathrm{pH}_{\mathrm{PZC}}(\mathrm{pH} 4),>\mathrm{pH} \mathrm{PZC}_{\mathrm{CH}}(\mathrm{pH})$, and $<\mathrm{pH}_{\mathrm{PZC}}(\mathrm{pH} 3)$ for 1- and 180-day of incubation. IKS in the label represents IKJ 583, "L" stands for low P-amendment, " $\mathrm{M}$ " for medium $\mathrm{P}$-amendment, and " $\mathrm{H}$ " for high $\mathrm{P}$-amendment. "PH1" in the samples label represents $>\mathrm{pH}_{\mathrm{PZC}}(\mathrm{pH} 7)$, “PH2" represents $\mathrm{pH}_{\mathrm{PZC}}(\mathrm{pH} 4)$, and "PH3" represents $<\mathrm{pH}_{\mathrm{PZC}}$ (pH 3). "POS_CTRL" stands for positive control. " $\mathrm{D}$ " represents for the days of incubation. 


\subsection{2. $\mathrm{BO}$}

The ICP-OES analysis conducted on the effluent samples of $\mathrm{BO}$ indicated that total soluble $\mathrm{Pb}$ was lowest with high $\mathrm{P}$-amendment at higher $\mathrm{pH}\left(>\mathrm{pH}_{\mathrm{PZC}}\right)$ similar to IKS (Table S3). Nonetheless, total dissolved As concentrations were lowest in the low $\mathrm{P}$-amended treatments set at $>\mathrm{pH}_{\mathrm{PZC}}$, indicating $\mathrm{pH}$ effect to be more predominant upon low P-application in reducing the total dissolved As concentration in effluent samples. This observation could be self-evident as a result of the known effect of competitive adsorption mechanism between arsenate and phosphate with high P-amendment, as described earlier.

Lead-XAS data analysis on post $\mathrm{P}$-amended samples at different $\mathrm{pHs}$ indicated $\mathrm{Pb}$ adsorbed to ferrihydrite (27\% to $37 \%$ ) and $\mathrm{Pb}$ bound to organic matter (15\% to $63 \%)$ as the primary dominant minerals [26] which are commonly observed in soil with high Fe oxides and high organic matter [48]. Adsorption of organic matter, especially humic substances, onto a mineral surface alters its physical and chemical properties, influencing the sorption and desorption processes of ions like phosphates and heavy metals. In addition, organic coatings on pyromorphite crystals seeds are also known to inhibit further pyromorphite formation $[49,50]$. These could be the reasons for observing low pyromorphite formation in all the treatment combinations of $\mathrm{BO}$ regardless of the different rate of P-applications. However, pyromorphite formation was slightly enhanced with high P-amendment (23\%) (Figure 3). This reduced phosphate fixation could be attributed to the competitive sorption of fulvic polyanions and their favorable sorption onto mineral particles [49]. The data obtained from other tested soils with three replicates showed higher consistency which indicates that there may not have been any limitations on the conclusion derived from only one replicate used in BO. However, long-term incubation for $\mathrm{BO}$ might derive more information on the trend of $\mathrm{Pb}$ - and As-bioaccessibility results over time.

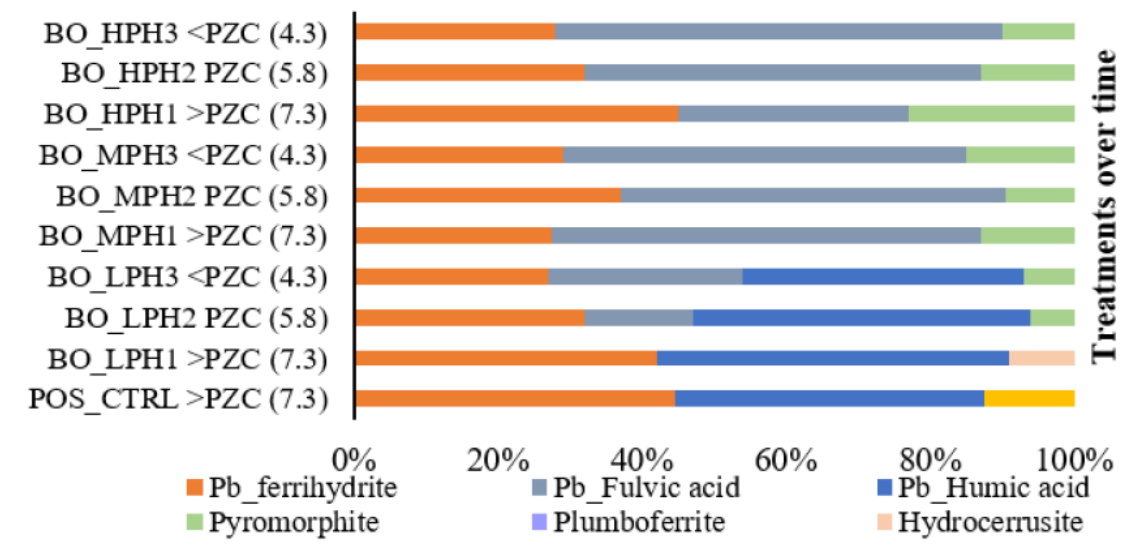

Figure 3. Bar chart represents the bulk $\mathrm{Pb}-\mathrm{XAS}$ results obtained via statistical analyses; principal component analysis (PCA), and linear combination fitting (LCF) showing \% components of Pb-minerals in low P-amended (1\%), medium P-amended (5\%), high P-amended (10\%) and non-amended positive control for $\mathrm{BO}$ at $\mathrm{pH}_{\mathrm{PZC}}(\mathrm{pH} 5.8),>\mathrm{pH}_{\mathrm{PZC}}(\mathrm{pH} 7.3)$, and $<\mathrm{pH}_{\mathrm{PZC}}(\mathrm{pH} 4.3)$ for 37-day of incubation. "L" in the sample labels stands for low P-amendment, " $\mathrm{M}$ " for medium $\mathrm{P}$-amendment, and " $\mathrm{H}$ " for high P-amendment. "PH1" in the samples label represents $>\mathrm{pH}_{\mathrm{PZC}}$, "PH2" represents $\mathrm{pH}_{\mathrm{PZC}}$, and "PH3" represents $<\mathrm{pH}_{\mathrm{PZC}}$. "POS_CTRL" stands for positive control.

The values for $\mathrm{Pb}$ TERs estimations in $\mathrm{BO}$ were $<1$, falling in the low to median range of 0.53 to 0.75 at $\mathrm{pH} 2.5$ and 0.66 to 0.79 at $\mathrm{pH} 1.5$ (Table 3). The presence of $\mathrm{Pb}$ sorbed to ferrihydrite in $\mathrm{BO}$ might have contributed significantly to the bioaccessible $\mathrm{Pb}$ pool, possibly because of dissolution and re-precipitation during IVBA extraction procedure [51-53]. 
Table 3. Treatment effect ratio (TER) for bioaccessible lead measurement at pH 1.5 and pH 2.5 for BO.

\begin{tabular}{ccc}
\hline \multirow{2}{*}{ Lead } & pH 1.5 & pH 2.5 \\
\cline { 2 - 3 } Treatment & \multicolumn{2}{c}{ Day 37 } \\
\hline BO_LPH1 > PZC (7.3) & 0.79 & TER \\
\hline BO_LPH2 PZC (5.8) & 0.79 & 0.75 \\
BO_LPH3 < PZC (4.3) & 0.77 & 0.71 \\
BO_MPH1 > PZC (7.3) & 0.77 & 0.72 \\
BO_MPH2 PZC (5.8) & 0.65 & 0.60 \\
BO_MPH3 < PZC (4.3) & 0.83 & 0.69 \\
BO_HPH1 > PZC (7.3) & 0.78 & 0.71 \\
BO_HPH2 PZC (5.8) & 0.66 & 0.60 \\
BO_HPH3 < PZC (4.3) & 0.82 & 0.53 \\
\hline Arsenic & & \\
\hline BO_LPH1 > PZC (7.3) & 1.12 & 1.12 \\
BO_LPH2 PZC (5.8) & 1.35 & 1.53 \\
BO_LPH3 < PZC (4.3) & 0.86 & 0.82 \\
BO_MPH1 > PZC (7.3) & 0.96 & 0.87 \\
BO_MPH2 PZC (5.8) & 1.11 & 1.12 \\
BO_MPH3 < PZC (4.3) & 0.72 & 0.60 \\
BO_HPH1 > PZC (7.3) & 0.90 & 0.75 \\
BO_HPH2 PZC (5.8) & 0.94 & 0.84 \\
BO_HPH3 < PZC (4.3) & 0.69 & 0.42 \\
\hline
\end{tabular}

Treatment effect ratio (TER) represents the bioaccessibility in amended soil divided by bioaccessibility in the untreated soil at that particular pH. BO in the label represents Barber orchard soil, "L" stands for low P-amendment, " $\mathrm{M}$ " for medium P-amendment, and " $\mathrm{H}$ " for high P-amendment. "PH1" in the samples label represents $>\mathrm{pH} \mathrm{HZC}_{\mathrm{PZC}}$ (pH 7.3) "PH2" represents $\mathrm{pH}_{\mathrm{PZC}}\left(\mathrm{pH}\right.$ 5.8), and "PH3" represents < $\mathrm{pH}_{\mathrm{PZC}}(\mathrm{pH}$ 4.3).

Arsenic speciation in post-amended BO indicated $\mathrm{As}(\mathrm{V})$ sorbed to goethite (11\% to $43 \%)$, As sorbed to birnessite (12\% to $49 \%$ ), arseniosiderite (19\% to $37 \%$ ), and $\mathrm{Pb}$-arsenate pesticide ( $12 \%$ to $30 \%$ ) (Figure 4). Considering an initial As mineralogy, competitive retention of As between Fe and Mn oxides was observed as arsenic sorbed to birnessite was decreased and redistributed to goethite. This increased preferential partition of $\mathrm{As}(\mathrm{V})$ from birnessite to goethite could be a result of higher adsorption affinity of As with goethite compared to birnessite [54]. The presence of $\mathrm{Pb}$-arsenate pesticide $\left(\mathrm{PbHAsO}_{4}\right)$ confirms its established properties as relatively insoluble and persistent. Approximately $17 \%$ to $37 \%$ of arseniosiderite $\left(\mathrm{Ca}_{2} \mathrm{Fe}_{3}{ }^{3+} \mathrm{O}_{2}\left(\mathrm{AsO}_{4}\right)_{3} \cdot 3 \mathrm{H}_{2} \mathrm{O}\right)$ was formed in the post-amended $\mathrm{BO}$ at $\mathrm{pH}$ PZC. Literature is limited on understanding the conditions promoting arseniosiderite formation and dissolution.

In the current study, formation of arseniosiderite displayed the influence of adsorption and precipitation reaction in Fe-rich aqueous environment favored with the $\mathrm{Ca} / \mathrm{As}+\mathrm{Fe}+\mathrm{Ca}$ ratio of 0.13 (required: 0.1 ) and the $\mathrm{pH}$ of slightly acidic to alkaline (4.3 to 7.3) as minimum requirements for arseniosiderite formation [55]. The TERs estimations for As in BO were usually high, yet values of 0.42 ( $\mathrm{pH}$ 2.5) and 0.69 (pH 1.5) were observed in HPH3 at $\mathrm{pH} 4.3$ (Table 3). Among oxides of Fe/ $\mathrm{Al} / \mathrm{Mn}$, Fe-oxide minerals, such as hydrous ferric oxide (HFO), goethite, and hematite, are considered to be the most important sinks for As under-oxidized conditions [56,57]; still, the extent of adsorption depended upon the initial concentration, $\mathrm{pH}$, and competing ions present in solution [58]. High organic carbon $(\sim 7.2 \%)$ in BO may also have resulted in increased As TERs estimations. 


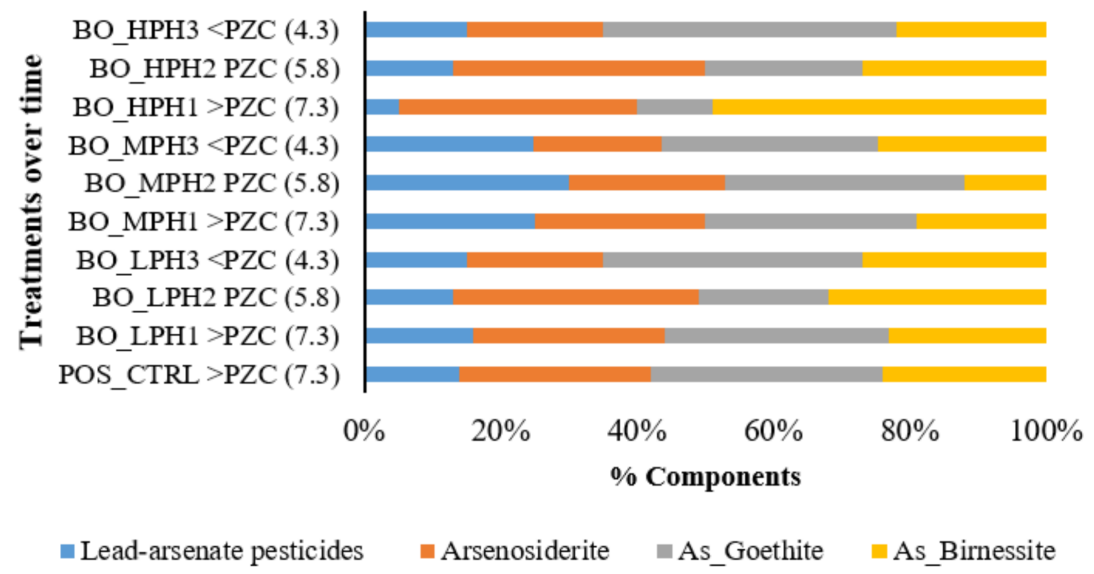

Figure 4. Bar chart represents the bulk As-XAS results obtained via statistical analyses; principal component analysis (PCA), and linear combination fitting (LCF) showing \% components of Pb-minerals in low $\mathrm{P}$-amended (1\%), medium $\mathrm{P}$-amended (5\%), high P-amended (10\%) and non-amended positive control for $\mathrm{BO}$ at $\mathrm{pH}_{\mathrm{PZC}}\left(\mathrm{pH}\right.$ 5.8), $>\mathrm{pH}_{\mathrm{PZC}}(\mathrm{pH} 7.3)$, and $<\mathrm{pH}_{\mathrm{PZC}}(\mathrm{pH} 4.3)$ for 37-day of incubation. " $\mathrm{L}$ " in the sample labels stands for low $\mathrm{P}$-amendment, " $\mathrm{M}$ " for medium $\mathrm{P}$-amendment, and " $\mathrm{H}$ " for high P-amendment.

\subsubsection{NW}

Total dissolved $\mathrm{Pb}$ concentration in NW indicated no noticeable difference with variable rate of $\mathrm{P}$-amendment at different $\mathrm{pHs}$. However, slightly enhanced soluble $\mathrm{Pb}$ was detected at $<\mathrm{pH}_{\mathrm{PZC}}$. A similar trend was observed with non-amended POS_CTRL indicating Pb was less soluble especially at circumneutral $\mathrm{pH}$. Total dissolved As in NW displayed a similar trend as IKS where soluble As was least detected at $>\mathrm{pH}_{\mathrm{PZC}}$ and with low P-amendment (Table S4).

Lead mineralogy in post-amended treatments of NW (Figure 5) showed slight alterations as $\mathrm{Pb}$ sorbed to humic acids and $\mathrm{Pb}$ sorbed to ferrihydrite were both identified as primary dominant phases ( $20 \%$ to $80 \%$ ). The other minor Pb-minerals included lead phosphates, magnetoplumbite, $\mathrm{Pb}$ sorbed to hydroxyapatite, cerussite, and anglesite, among which $\mathrm{Pb}$-phosphates were frequently observed at higher $\mathrm{pH}$ which was supported by reduction in phosphate (anions) measurements at $>\mathrm{pH}$ PZC (Table S6). However, no particular trend in Pb-phosphate formation was observed. Among the two dominant minerals, $\mathrm{Pb}$ sorbed to ferrihydrite decreased (from $90 \%$ to $12 \%$ ), whereas $\mathrm{Pb}$ sorbed to humic acids showed an increasing trend (12\% to $90 \%$ ) from day-1 to day-180 of incubation (Figure 5). In $\mathrm{NW}$, redistribution of $\mathrm{Pb}$ from mineral surfaces to organic matter at higher $\mathrm{pH}\left(>\mathrm{pH}_{\mathrm{PZC}}\right.$ of 8 ) was likely related to the strong affinity of $\mathrm{Pb}$ (II) to partition on organic matter either via electrostatic or chemical bonds with surface functional groups which decreases with a decrease in $\mathrm{pH}$, as supported by Cao et al. [5] and Wang et al. [59].

Despite fairly similar mineralogy, across the treatments, TERs estimations for $\mathrm{Pb}$ bioaccessibility measurements were 0.50 to 0.72 at $\mathrm{pH} 2.5$, and $\sim 0.6$ at $\mathrm{pH} 1.5$ in the treatment set at $>\mathrm{pH}_{\mathrm{PZC}}$ with both medium and high P-amendments, whereas the highest $\mathrm{Pb}$ TER estimation stayed between 1.19 to 1.33 with low P-amendment at higher pHs in NW (Table 4). 
a.
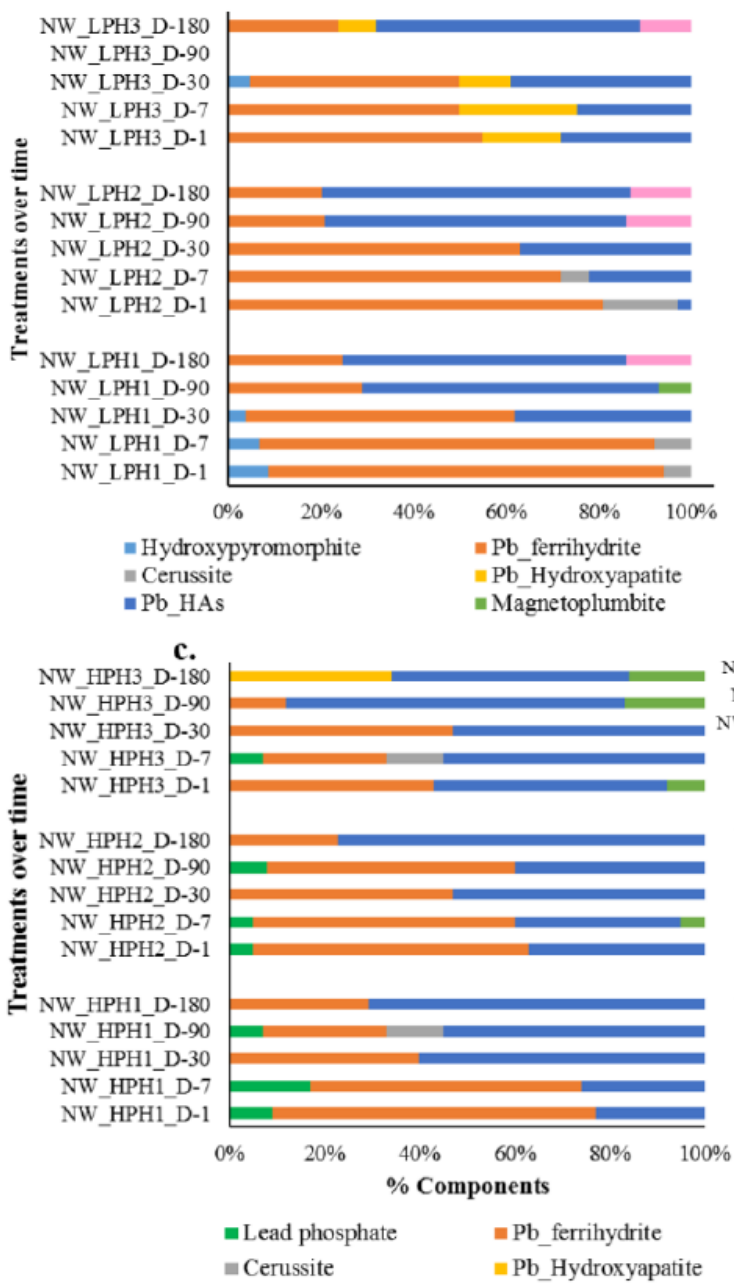

b.

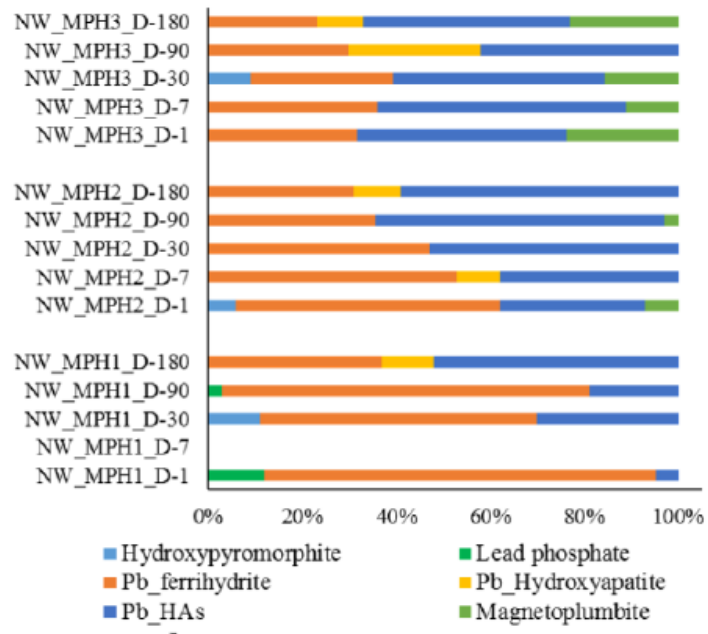

d.

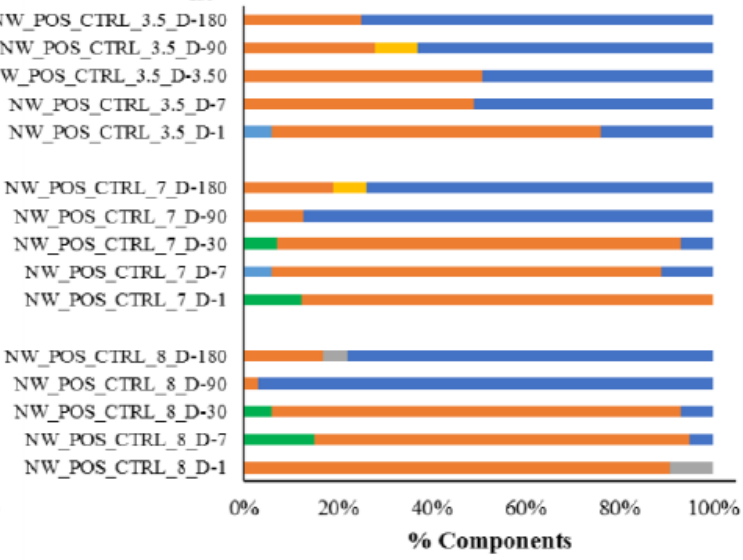

=Hydroxypyromorphite $\quad$ Lead phosphate $\quad=\mathrm{Pb}$ ferrihydrite $=$ Cerussite $\quad$ Pb_Hydroxyapatite $\quad$ Pb_HAs

Figure 5. Bar chart represents the bulk $\mathrm{Pb}-\mathrm{XAS}$ results obtained via statistical analyses; principal component analysis (PCA), and linear combination fitting (LCF) showing \% components of Pb-minerals in (a) Low P-amended (1\%) (b) Medium P-amended (5\%), (c) High P-amended (10\%) and (d) non-amended positive control for $\mathrm{NW}$ at $\mathrm{pH}_{\mathrm{PZC}}(\mathrm{pH} 7),>\mathrm{pH}_{\mathrm{PZC}}(\mathrm{pH} 8)$, and $<\mathrm{pH}_{\mathrm{PZC}}(\mathrm{pH} 3.5)$ at 1-, 7-, 30-, 90-, and 180-day of incubation. " $\mathrm{L}$ " in the sample labels stands for low P-amendment, " $\mathrm{M}^{\prime}$ for medium $\mathrm{P}$-amendment, and " $\mathrm{H}$ " for high $\mathrm{P}$-amendment. "PH1" in the samples label represents $>\mathrm{pH}_{\mathrm{PZC}}$, "PH2" represents $\mathrm{pH}$ PZC, and "PH3" represents < $\mathrm{pH}_{\mathrm{PZC}}$. "POS_CTRL" stands for positive control. " $\mathrm{D}$ " represents for the days of incubation.

Arsenic speciation in NW with very low As concentration (19 $\left.\mathrm{mg} \mathrm{kg}^{-1}\right)$ (Table 1) indicated the presence of $\mathrm{As}(\mathrm{V})$ _jarosite and scorodite as the predominant minerals with $\mathrm{As}(\mathrm{V})$ sorbed to birnessite, $\mathrm{As}(\mathrm{V})$ sorbed to goethite, As(V) sorbed to ferrihydrite, loellingite, and arseniosiderite as the minor minerals. While mineralogical composition remained almost similar, there were increments in $\%$ component of As(V)_jarosite (from 18\% to 48\%) and scorodite (from 13\% to 55\%) in all the treatment combinations compared to As-speciation in the starting NW used in this study. Overall, TER As values were lower for all high P-amended samples at all pHs; however, the smallest TER value (0.42) was estimated at $>\mathrm{pH}_{\mathrm{PZC}}$ which could be a result of the presence of more stable As minerals such as $\mathrm{As}(\mathrm{V})$ _jarosite and scorodite as well as the possible formation of insoluble calcium arsenate at higher $\mathrm{pH}$ (Figure 6). This speculation can also be supported by soluble Ca data provided in Table S4. Arsenic incorporation in the jarosite structure could have potentially increased the stabilization of the jarosite structure and decreased its solubility, as reported by Baron and Palmer [60]. In addition, scorodite is 
known as one of the least bioaccessible $(0.13 \%)$ with (log Ksp of -25.8) arsenate phases reported in mining-impacted soils [61].

Table 4. Treatment effect ratio (TER) for bioaccessible lead measurement at $\mathrm{pH} 1.5$ and $\mathrm{pH} 2.5$ for NW.

\begin{tabular}{|c|c|c|c|c|c|c|c|c|c|c|}
\hline \multirow{2}{*}{ Lead } & \multicolumn{5}{|c|}{ pH 1.5} & \multicolumn{5}{|c|}{$\mathrm{pH} 2.5$} \\
\hline & Day 1 & Day 7 & Day 30 & Day 90 & Day 180 & Day 1 & Day 7 & Day 30 & Day 90 & Day 180 \\
\hline NW_LPH1 > PZC (8.0) & 1.01 & 0.93 & 0.91 & 0.96 & 0.97 & 0.91 & 0.89 & 0.97 & 0.92 & 1.00 \\
\hline NW_LPH2 PZC (7.0) & 1.02 & 0.92 & 0.89 & 0.92 & 0.99 & 0.95 & 0.85 & 0.89 & 0.84 & 0.95 \\
\hline NW_LPH3 < PZC (3.5) & 0.95 & 0.91 & 1.11 & 1.17 & 1.19 & 0.97 & 1.05 & 1.10 & 1.24 & 1.33 \\
\hline NW_MPH1 > PZC (8.0) & 0.94 & 0.90 & 0.86 & 0.93 & 0.97 & 0.71 & 0.70 & 0.80 & 0.74 & 0.81 \\
\hline NW_MPH2 PZC (7.0) & 0.98 & 0.88 & 0.85 & 0.89 & 0.93 & 0.75 & 0.63 & 0.72 & 0.66 & 0.79 \\
\hline NW_MPH3 < PZC (3.5) & 0.94 & 0.95 & 1.12 & 1.14 & 1.22 & 0.98 & 1.00 & 1.05 & 1.08 & 1.21 \\
\hline NW_HPH1 > PZC (8.0) & 0.94 & 0.93 & 0.85 & 0.88 & 0.93 & 0.69 & 0.67 & 0.75 & 0.64 & 0.69 \\
\hline NW__HPH2 PZC (7.0) & 0.97 & 0.86 & 0.86 & 0.84 & 0.93 & 0.67 & 0.59 & 0.67 & 0.64 & 0.69 \\
\hline NW_HPH3 < PZC (3.5) & 0.96 & 0.93 & 1.12 & 1.09 & 1.11 & 0.93 & 0.95 & 0.94 & 0.95 & 1.07 \\
\hline \multirow{2}{*}{ Arsenic } & \multicolumn{5}{|c|}{ pH 1.5} & \multicolumn{5}{|c|}{ pH 2.5} \\
\hline & Day 1 & Day 7 & Day 30 & Day 90 & Day 180 & Day 1 & Day 7 & Day 30 & Day 90 & Day 180 \\
\hline Treatment & TER & TER & TER & TER & TER & TER & TER & TER & TER & TER \\
\hline NW_LPH1 > PZC (8.0) & 1.16 & 1.06 & 1.11 & 1.15 & 1.18 & 1.09 & 1.09 & 1.21 & 1.27 & 1.22 \\
\hline NW_LPH2 PZC (7.0) & 1.09 & 1.02 & 0.97 & 1.03 & 1.55 & 1.12 & 1.05 & 1.14 & 1.05 & 1.01 \\
\hline NW_LPH3 < PZC (3.5) & 0.88 & 0.84 & 0.98 & 1.00 & 1.06 & 0.91 & 0.95 & 0.86 & 1.04 & 1.08 \\
\hline NW_MPH1 > PZC (8.0) & 1.04 & 1.04 & 1.03 & 1.23 & 1.13 & 0.95 & 1.01 & 1.09 & 1.28 & 1.19 \\
\hline NW__MPH2 PZC (7.0) & 0.92 & 0.92 & 0.96 & 1.07 & 1.02 & 0.93 & 1.32 & 0.96 & 1.01 & 0.81 \\
\hline NW_MPH3 < PZC (3.5) & 0.75 & 0.76 & 0.75 & 0.74 & 0.75 & 0.89 & 0.82 & 0.73 & 0.70 & 0.76 \\
\hline NW_HPH1 > PZC (8.0) & 0.79 & 0.71 & 0.61 & 0.55 & 0.54 & 0.73 & 0.64 & 0.50 & 0.43 & 0.42 \\
\hline NW_HPH2 PZC (7.0) & 0.76 & 0.63 & 0.60 & 0.56 & 0.82 & 0.72 & 0.90 & 0.52 & 0.47 & 0.45 \\
\hline NW_HPH3 < PZC (3.5) & 0.64 & 0.69 & 0.65 & 0.60 & 0.62 & 0.72 & 0.73 & 0.59 & 0.50 & 0.59 \\
\hline
\end{tabular}

Treatment effect ratio (TER) represents the bioaccessibility in amended soil divided by bioaccessibility in the untreated soil at that particular pH. NW in the label represents Northwestern soils, "L" stands for low P-amendment, " $\mathrm{M}$ " for medium P-amendment, and " $\mathrm{H}$ " for high P-amendment. "PH1" in the samples label represents $>\mathrm{pH}_{\mathrm{PZC}}$ $(\mathrm{pH} 8)$ "PH2" represents $\mathrm{pH}_{\mathrm{PZC}}(\mathrm{pH} 7)$, and "PH3" represents $<\mathrm{pH}_{\mathrm{PZC}}(\mathrm{pH} 3.5)$.

Overall, the current study indicated very slight $\mathrm{Pb}$ and As mineralogical changes with different rates of $\mathrm{P}$-application in combination with $\mathrm{pH}$ set at, above, and below PZC. No significant role of PZC was observed in pyromorphite formation. While the $\mathrm{pH}-\mathrm{PZC}$ relationship may not have had a significant impact on $\mathrm{Pb}$ and As mineralogy, there were significant differences in the measured TER values for $\mathrm{As}$ and $\mathrm{Pb}$ after $\mathrm{P}$-amendment. A one-way ANOVA was conducted on the individual factors in the study which would have influenced the change in $\mathrm{Pb}$ and As bioaccessibility (pH-PZC relationship, P-application, and time). Across the three, the only significant factor contributing to a change in the TER for $\mathrm{Pb}$ or As was the $\mathrm{pH}-\mathrm{PZC}$ relationship $\left(\mathrm{ANOVA}_{\mathrm{TER}-\mathrm{Pb}}, \mathrm{F}=26.6, p\right.$-value $<0.001$ and ANOVA TER-As, $_{\text {F }}=20.79, p$-value $\left.<0.001\right)$. Additional factors, P-application, and time were not significant. To further evaluate potential interactions between the $\mathrm{pH}-\mathrm{PZC}$ relationship and P-application or between the $\mathrm{pH}-\mathrm{PZC}$ relationship and time, a two-way ANOVA was conducted. Results from the analysis did not indicate there were any significant interactions between the factors. Posthoc Tukey's means comparisons for the different $\mathrm{pH}-\mathrm{PZC}$ relationships revealed that the TER $\mathrm{Pb}$ values for all three means were statistically different from one other with the $\mathrm{pH}>\mathrm{PZC}$ having the minimum value (Figure 7). The Tukey's means comparison for TER $\mathrm{As}_{\mathrm{s}}$ value indicated no difference between the mean $\mathrm{TER}_{\mathrm{As}}$ value for $\mathrm{pH}=\mathrm{PZC}$ or $\mathrm{pH}>\mathrm{PZC}$. However, the $\mathrm{TER}_{\mathrm{As}}$ value was significantly lower when the $\mathrm{pH}<\mathrm{PZC}$ after P-amendment. 
a.

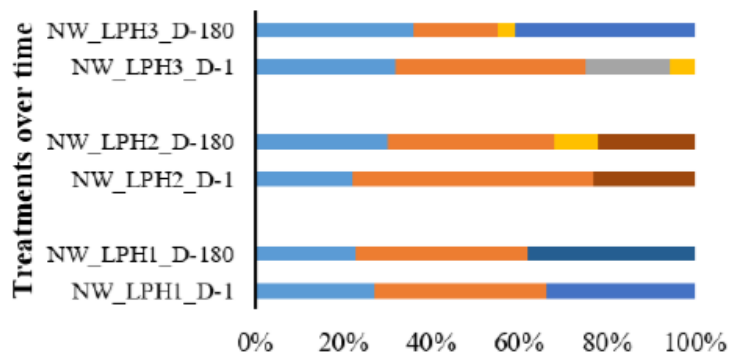

c.

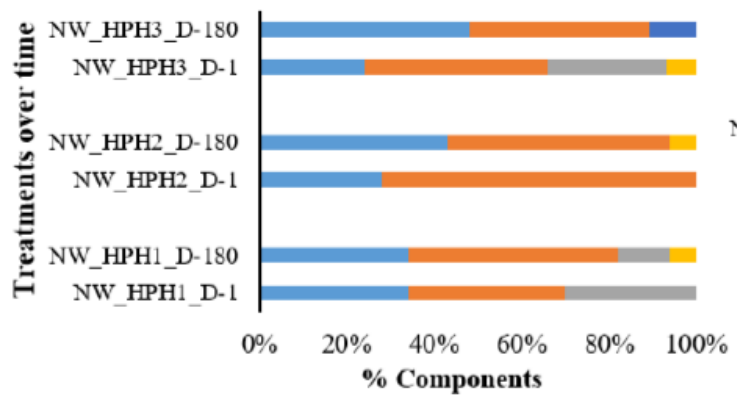

= As_Jarosite $=$ Scorodite $=$ As_Ferrihydrite $=$ Loellingite $=$ As_Goethite b.

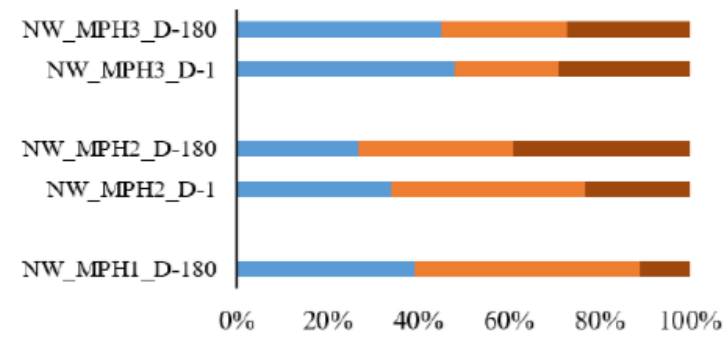

d.

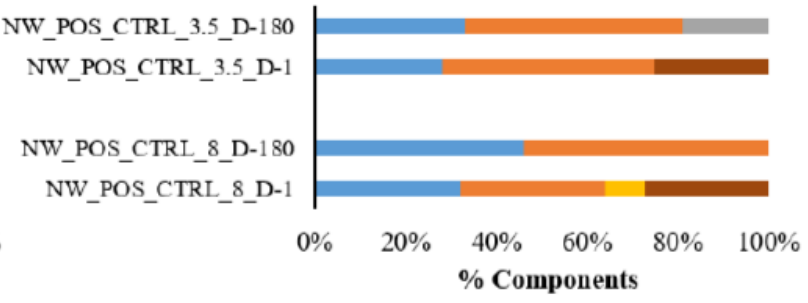

= As_Jarosite $\quad$ Scorodite $=$ As_Ferrihydrite $=$ Loellingite

- As_Goethite $=$ Arsenosiderite $=$ As_Birnessite

Figure 6. Bar chart represents the bulk As-XAS results obtained via statistical analyses; principal component analysis (PCA), and linear combination fitting (LCF) showing \% components of Pb-minerals in (a) Low P-amended (1\%); (b) Medium P-amended (5\%); (c) High P-amended (10\%) and (d) non-amended positive control for $\mathrm{NW}$ at $\mathrm{pH}_{\mathrm{PZC}}(\mathrm{pH} 4),>\mathrm{pH}_{\mathrm{PZC}}(\mathrm{pH} 7)$, and $<\mathrm{pH}_{\mathrm{PZC}}(\mathrm{pH} 3)$ for 1- and 180-day of incubation. " $\mathrm{D}$ " represents for the days of incubation.
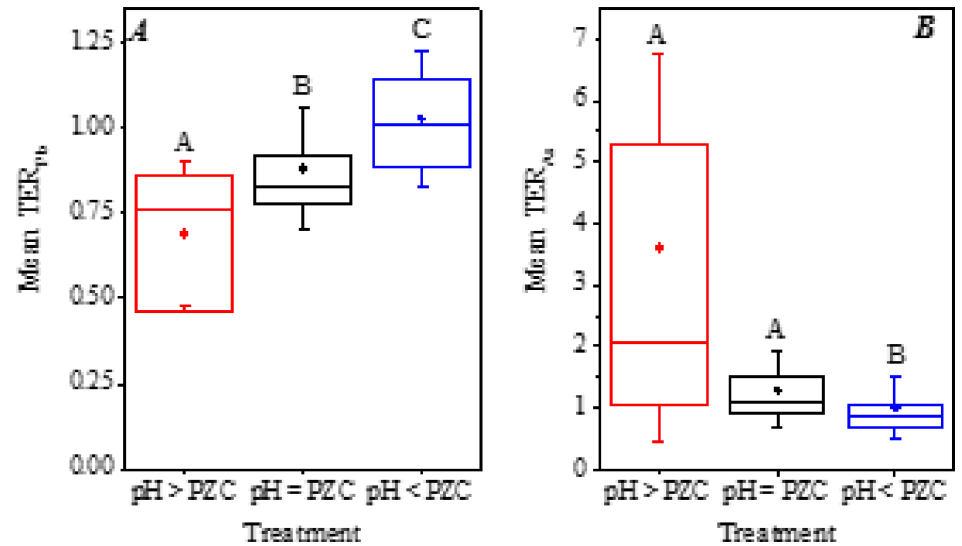

Figure 7. Box and whisker plots for the mean TER values for $\mathrm{Pb}$ and $\mathrm{As}$ as a function of the $\mathrm{pH}-\mathrm{PZC}$ relationship. The mean is represented by the symbol in each box and whisker plot. The box ends represent the 25th and 75th percentiles, while the middle line is equal to the median value. The whiskers

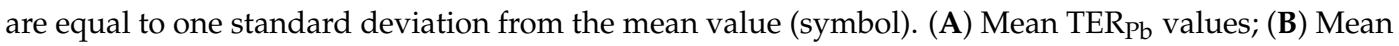
$\mathrm{TER}_{\text {As }}$ values.

The total number of TER measurements for each soil type based on each treatment factor ( $\mathrm{pH}-\mathrm{PZC}$ relationship, P-loading, and time) was 9, 45, and 54 for $\mathrm{BO}, \mathrm{NW}$, and IKS, respectively. As a result of an unbalanced design with respect to the number of TER measurements collected for each soil type, it was not possible to determine if the soil type was a significant factor related to the changes 
in bioaccessibility after P-amendment. However, a visual comparison of the mean $T E R_{\mathrm{Pb}}$ and $T E R_{\mathrm{As}}$ values as a function of soil type indicated that there was a slight difference among the TER $\mathrm{Pb}_{\mathrm{P}}$ value calculated for all of the pH-PZC conditions evaluated (Supplemental Figure S2). The range of values obtained for the IKS soil showed a much higher degree of variability compared to the BO and NW soils. Further analysis of the range of TER values for $\mathrm{Pb}$ and $\mathrm{As}$ as a function of the $\mathrm{pH}-\mathrm{PZC}$ relationship were analyzed to assess how soil properties may influence the measured TER (Figure 8). The data presented in Figure 8 would indicate that soil type is an important factor along with the pH-PZC relationship when considering changes in bioaccessible $\mathrm{As}$ and $\mathrm{Pb}$ in $\mathrm{P}$ amended soils. As previously noted, the range of TER values for each $\mathrm{pH}-\mathrm{PZC}$ for the IKS was much greater than the range of values for the other two soils (Figure S2) and the response of the measured TER value between different $\mathrm{pH}-\mathrm{PZC}$ relationships; As and $\mathrm{Pb}$ was greatest for IKS. IKS differed from the other two soils in the amount of Fe present (14\% by weight), $\mathrm{S}$ ( $8.5 \%$ by weight), and the large concentration of As (3850 $\left.\mathrm{mg} \mathrm{kg}^{-1}\right)$. It is likely the large TER $\mathrm{As}_{\mathrm{As}}$ value measured for IKS, when the $\mathrm{pH}$ was less than the PZC ( $\mathrm{pH} 3$ ), was a result of Fe mineral dissolution because the majority of As species present in the soil were associated with scorodite and As-adsorbed to iron oxides (Figure 2 and Table S2). Even the dissolution of a small amount of Fe could have a large impact on the bioaccessible fraction of As. The reduced TER $\mathrm{Pb}$ value for IKS compared to $\mathrm{BO}$ and $\mathrm{NW}$ at $>\mathrm{pH}_{\mathrm{PZC}}$ was likely related to the $\mathrm{Pb}$ speciation. IKS $\mathrm{Pb}$ speciation was dominated by a crystalline form of $\mathrm{Pb}$, plumbojarosite, making it less likely to be released during the in vitro extraction compared to sorbed $\mathrm{Pb}$ species which were dominant in the NW and BO. As the $\mathrm{pH}$ decreased toward and below the PZC (pH 4 and 3) in IKS, the solubility of jarosite minerals increased, thus allowing for increased extraction of $\mathrm{Pb}$ due to dissolution at the mineral surface.
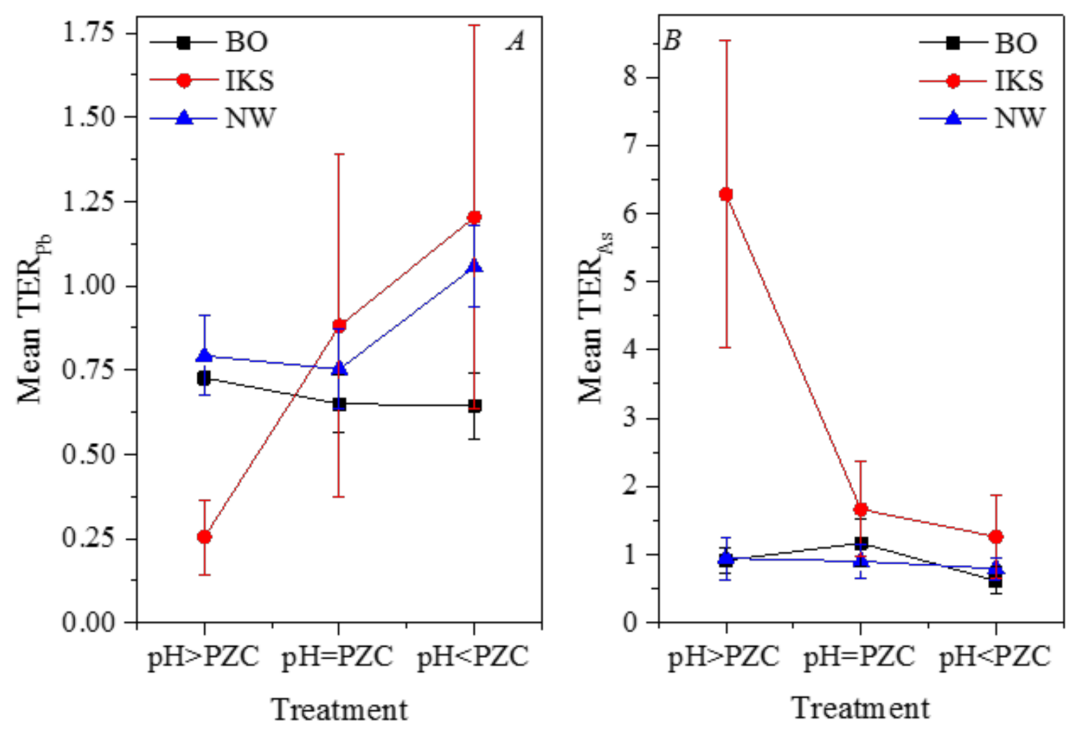

Figure 8. Mean TER values for the three $\mathrm{pH}-\mathrm{PZC}$ relationships for individual soil types tested. The error bars represent one standard deviation from the mean value (symbol). (A) Mean TER $\mathrm{Pb}_{\text {values; }}$ (B) Mean TER As values.

\section{Conclusions}

Phosphate amendments have been recommended for mitigating the risk associated with $\mathrm{Pb}$ by forming highly insoluble $\mathrm{Pb}$ species such as pyromorphite. The formation of insoluble pyromorphite in P-amended soils have been considerably successful in lab-based studies, but limited success has been found in field studies. Focused studies to investigate mechanisms to promote pyromorphite formation in field studies are needed to facilitate utilization of this technology. This study proposed to examine the role of PZC in combination with different rates of P-applications in pyromorphite 
formation and bioaccessibility of $\mathrm{Pb}$ and $\mathrm{As}$ in phosphate-amended soils. Overall, the results obtained from the current study indicated that there was no significant effect of PZC on pyromorphite formation in P-amended soils; however, the TER for Pb bioaccessibility appeared to be lower when $\mathrm{pH}>\mathrm{PZC}$. In contrast, the As TER was lower when $\mathrm{pH}<\mathrm{PZC}$ in all three tested soils. In particular, the reduced $\mathrm{TER}_{\mathrm{Pb}}$ value for IKS compared to $\mathrm{BO}$ and NW when $\mathrm{pH}>\mathrm{PZC}$, was likely related to the $\mathrm{Pb}$ speciation dominated by a crystalline form of $\mathrm{Pb}$, plumbojarosite. This made it less likely to be released during the in vitro extraction compared to sorbed $\mathrm{Pb}$ species which were dominant in $\mathrm{NW}$ and $\mathrm{BO}$. In contrast,

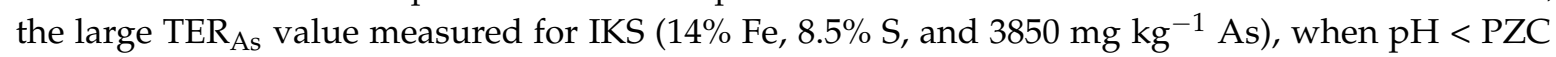
was a result of Fe-mineral dissolution as the majority of As species present in the soil were associated with scorodite and As-adsorbed to iron oxides. High organic matter content in $\mathrm{BO}(\sim 7.2 \%)$ was likely an inhibitor of pyromorphite formation due to occlusion; nevertheless, high Fe and Mn content and associated more stable minerals present in the tested soils might have been responsible in reducing the bioaccessibility of both $\mathrm{Pb}$ and As over time. Higher Ca content in NW may have resulted in the formation of insoluble calcium phosphates at $\mathrm{pH}>\mathrm{PZC}$ due to its adsorption site competition with $\mathrm{Pb}$ thereby inhibiting pyromorphite formations. However, the TER for $\mathrm{Pb}$ in $\mathrm{NW}$ was reduced at $\mathrm{pH}>\mathrm{PZC}$ attributable to the redistribution of lead to organics bound in combination with high $\mathrm{pH}$. Overall, lower TER values for As was observed for high P-amended NW samples; however, the smallest TER for As was estimated for the high P-amended samples at $>\mathrm{pH}$ PZC which was likely a result of the more stable As mineralogy as well as possible calcium arsenate formation at high $\mathrm{pH}$.

However, caution must be taken for phosphate-amended soils in which competitive reactions may enhance contaminant mobility and bioavailability, such as the case of As in this study. The lack of conversion of soil $\mathrm{Pb}$ to pyromorphite may be attributed to several reasons, possibly a result of the presence of highly stable minerals, such as plumbojarosite, which limits soluble $\mathrm{Pb}$ availability to react with phosphates. The speculations discussed above are also supported by the data obtained from a similar study conducted by using $\mathrm{Pb}$-acetate spiked soils ( $3000 \mathrm{mg} \mathrm{Pb}$ per $\mathrm{kg}$ of soil, equilibrated for two weeks under $40 \%$ field capacity and room temperature). The TER data obtained over 30-day of incubation (Table S8) indicated lower values at higher $\mathrm{pH}$ which was similar to other tested soils in this study. However, Pb-XAS data indicated increased pyromorphite formation (Figure 1) at higher $\mathrm{pH}$. The newly spiked soil used in this study lacked highly stable minerals; instead, they were mostly dominated by sorbed $\mathrm{Pb}$ phases. The presence of $\mathrm{Pb}$ species with higher dissolution rates enhanced pyromorphite formation in the newly spiked soils. Additional aged soils need to be tested in order to confirm the role of PZC on pyromorphite formations in P-amended soils.

Supplementary Materials: There are eight supplementary tables and three supplementary figures provided in this document. The following are available online at http:/ / www.mdpi.com/2571-8789/2/2/22/s1. Table S1: Recovery percentage for QA/QC samples during a) lead and arsenic IVBA extraction procedure (EPA Method 1340), and b) EPA 3051A acid digestion. Table S2: Total dissolved elements measurement from effluent samples collected from IKJ 583 at 1-, 7-, 30, 90-, and 180-day of incubation using ICP-OES. Table S3: Total dissolved elements measurement in effluent samples collected from BO at 37-day of incubation using ICP-OES. Table S4: Total dissolved elements measurement in effluent samples collected from NW at 1-, 7-, 30, 90-, and 180-day of incubation using ICP-OES. Table S5: Sulfate and phosphate measurements in IKJ 583. Table S6: Sulfate and phosphate measurements in NW. Table S7: Sulfate and phosphate measurements in BO. Table S8: Treatment effect ratio (TER) for bioaccessible lead measurement at $\mathrm{pH} 1.5$ and $\mathrm{pH} 2.5$ for artificially spiked soil (CS). Figure S1: Bar chart represents the bulk $\mathrm{Pb}-\mathrm{XAS}$ results obtained via statistical analyses; principal component analysis (PCA), and linear combination fitting (LCF) results showing \% components of Pb-minerals in a) Medium P-amended (5\%) of artificially lead-spiked soil $>$ pHPZC ( $\mathrm{pH} 7.5,8.5)$, and $<\mathrm{pHPZC}(\mathrm{pH} 3.5)$ for 1-, 7-, 30-day of incubation. CS in the label represents clean soil spiked with lead, "M" stands for medium P-amendment. "PH1" and "PH2" in the samples label represents $>$ pHPZC, and "PH3" represents < pHPZC. "POS_CTRL" stands for positive control. Figure S2: Box and whisker plots for the mean TER values for $\mathrm{Pb}$ and $\mathrm{As}$ as a function of soil type. The mean is represented by the symbol in each box and whisker plot. The box ends represent the 25th and 75th percentiles, while the middle line is equal to the median value. The whiskers are equal to one standard deviation from the mean value (symbol). (A) Mean TERPb values, (B) Mean TERAs values. Figure S3: Dissolved Fe concentration for the IKS soil for each of the three $\mathrm{pH}-\mathrm{PZC}$ relationships at the P-application rate of $1 \%$.

Acknowledgments: The US EPA funded and managed the research described here. It has been subjected to agency review and approved for publication. Mention of trade names or commercial products does not constitute endorsement or recommendation for use. We acknowledge the support of the Materials Research Collaborative 
Access Team (MRCAT) (Sector 10-ID, and 10-BM). The MRCAT operations are supported by the Department of Energy and the MRCAT member institutions. This research used resources of the Advanced Photon Source, a US Department of Energy (DOE) Office of Science User Facility operated for the DOE Office of Science by Argonne National Laboratory under contract no. DE-AC02-06CH11357. We are also thankful to Jennifer Goetz and Aaron Betts for their help during the initial phase of experiment setup.

Author Contributions: R.R.K. conceived, designed, and performed the experiments with the support of K.G.S., and wrote the paper with input from K.G.S. and M.N.; K.G.S. assisted in collecting the XAS data at APS; T.P.L. assisted to conduct the statistical analysis and review the manuscript.

Conflicts of Interest: The authors declare no conflict of interest.

\section{References}

1. Hettiarachchi, G.M.; Pierzynski, G.M. Soil lead bioavailability and in situ remediation of lead-contaminated soils: A review. Environ. Prog. Sustain. Energy 2004, 23, 78-93. [CrossRef]

2. Porter, S.K.; Scheckel, K.G.; Impellitteri, C.A.; Ryan, J.A. Toxic metals in the environment: Thermodynamic considerations for possible immobilization strategies for $\mathrm{Pb}, \mathrm{Cd}, \mathrm{As}$, and $\mathrm{Hg}$. Crit. Rev. Environ. Sci. Technol. 2004, 34, 495-604. [CrossRef]

3. Scheckel, K.G.; Ryan, J.A. Spectroscopic speciation and quantification of lead in phosphate-amended soils. J. Environ. Qual. 2004, 33, 1288-1295. [CrossRef] [PubMed]

4. US EPA. Q's and A's Fact Sheet on MTBE in Water; Office of Water: Washington, DC, USA, 1996.

5. Cao, X.; Wahbi, A.; Ma, L.; Li, B.; Yang, Y. Immobilization of Zn, Cu, and Pb in contaminated soils using phosphate rock and phosphoric acid. J. Hazard. Mater. 2009, 164, 555-564. [CrossRef] [PubMed]

6. Hettiarachchi, G.M.; Pierzynski, G.M.; Ransom, M.D. In situ stabilization of soil lead using phosphorus and manganese oxide. Environ. Sci. Technol. 2000, 34, 4614-4619. [CrossRef]

7. Ma, Q.Y.; Traina, S.J.; Logan, T.J.; Ryan, J.A. In situ lead immobilization by apatite. Environ. Sci. Technol. 1993, 27, 1803-1810. [CrossRef]

8. Nriagu, J.O. Lead orthophosphates-IV Formation and stability in the environment. Geochim. Cosmochim. Acta 1974, 38, 887-898. [CrossRef]

9. Scheckel, K.G.; Diamond, G.L.; Burgess, M.F.; Klotzbach, J.M.; Maddaloni, M.; Miller, B.W.; Partridge, C.R.; Serda, S.M. Amending soils with phosphate as means to mitigate soil lead hazard: A critical review of the state of the science. J. Toxicol. Environ. Health 2013, 16, 337-380. [CrossRef] [PubMed]

10. Chappell, M.A.; Scheckel, K.G. Pyromorphite formation and stability after quick lime neutralisation in the presence of soil and clay sorbents. Environ. Chem. 2007, 4, 109-113. [CrossRef]

11. Zhang, P.; Ryan, J.A.; Yang, J. In vitro soil $\mathrm{Pb}$ solubility in the presence of hydroxyapatite. Environ. Sci. Technol. 1998, 32, 2763-2768. [CrossRef]

12. Butkus, M.A.; Johnson, M.C. Reevaluation of phosphate as a means of retarding lead transport from sandy firing ranges. Soil Sediment Contam. 2011, 20, 172-187. [CrossRef]

13. Debela, F.; Arocena, J.; Thring, R.; Whitcombe, T. Organic acid-induced release of lead from pyromorphite and its relevance to reclamation of Pb-contaminated soils. Chemosphere 2010, 80, 450-456. [CrossRef] [PubMed]

14. Darland, J.E.; Inskeep, W.P. Effects of $\mathrm{pH}$ and phosphate competition on the transport of arsenate. J. Environ. Qual. 1997, 26, 1133-1139. [CrossRef]

15. Peryea, F.; Kammereck, R. Phosphate-enhanced movement of arsenic out of lead arsenate-contaminated topsoil and through uncontaminated subsoil. Water Air Soil Pollut. 1997, 93, 243-254. [CrossRef]

16. Brown, G.E., Jr.; Foster, A.L.; Ostergren, J.D. Mineral surfaces and bioavailability of heavy metals: A molecular-scale perspective. Proc. Natl. Acad. Sci. USA 1999, 96, 3388-3395. [CrossRef] [PubMed]

17. Barrow, N.; Bowden, J. A comparison of models for describing the adsorption of anions A on a variable charge mineral surface. J. Colloid Interface Sci. 1987, 119, 236-250. [CrossRef]

18. Lewis-Russ, A. Measurement of surface charge of inorganic geologic materials: Techniques and their consequences. Adv. Agron. 1991, 46, 199-243.

19. Sposito, G. On points of zero charge. Environ. Sci. Technol. 1998, 32, 2815-2819. [CrossRef]

20. Casteel, S.W.; Weis, C.P.; Henningsen, G.M.; Brattin, W.J. Estimation of relative bioavailability of lead in soil and soil-like materials using young Swine. Environ. Health Perspect. 2006, 114, 1162-1171. [CrossRef] [PubMed] 
21. Scheckel, K.G.; Chaney, R.L.; Basta, N.T.; Ryan, J.A. Advances in assessing bioavailability of metal (loid) $s$ in contaminated soils. Adv. Agron. 2009, 104, 1-52.

22. Isaure, M.; Laboudigue, A.; Manceau, A.; Sarret, G.; Tiffreau, C.; Trocellier, P.; Lamble, G.; Hazemann, J.; Chateigner, D. Quantitative Zn speciation in a contaminated dredged sediment by $\mu$-PIXE, $\mu$-SXRF, EXAFS spectroscopy and principal component analysis. Geochim. Cosmochim. Acta 2002, 66, 1549-1567. [CrossRef]

23. Karna, R.R.; Hettiarachchi, G.M.; Newville, M.; Sun, C.; Ma, Q. Synchrotron-based X-ray spectroscopy studies for redox-based remediation of lead, zinc, and cadmium in mine waste materials. J. Environ. Qual. 2016, 45, 1883-1893. [CrossRef] [PubMed]

24. Nachtegaal, M.; Marcus, M.; Sonke, J.; Vangronsveld, J.; Livi, K.; van Der Lelie, D.; Sparks, D. Effects of in situ remediation on the speciation and bioavailability of zinc in a smelter contaminated soil. Geochim. Cosmochim. Acta 2005, 69, 4649-4664. [CrossRef]

25. Roberts, D.R.; Scheinost, A.; Sparks, D. Zinc speciation in a smelter-contaminated soil profile using bulk and microspectroscopic techniques. Environ. Sci. Technol. 2002, 36, 1742-1750. [CrossRef] [PubMed]

26. Karna, R.R.; Noerpel, M.; Betts, A.R.; Scheckel, K.G. Lead and Arsenic Bioaccessibility and Speciation as a Function of Soil Particle Size. J. Environ. Qual. 2017, 46, 1225-1235. [CrossRef] [PubMed]

27. Schumacher, B.; Shines, K.; Burton, J.; Papp, M. Comparison of three methods for soil homogenization. Soil Sci. Soc. Am. J. 1990, 54, 1187-1190. [CrossRef]

28. US EPA. Method 3051a: Microwave Assisted Acid Dissolution of Sediments, Sludges, Soils, and Oils, 2nd ed.; US Government Print Office: Washington, DC, USA, 1997.

29. Sparks, D.L.; Fendorf, S.E.; Toner, C.V.; Carski, T.H. Kinetic Methods and Measurements; Soil Science Society of America, American Society of Agronomy: Madison, WI, USA, 1996.

30. Geebelen, W.; Adriano, D.; van der Lelie, D.; Mench, M.; Carleer, R.; Clijsters, H.; Vangronsveld, J. Selected bioavailability assays to test the efficacy of amendment-induced immobilization of lead in soils. Plant Soil 2003, 249, 217-228. [CrossRef]

31. Juhasz, A.L.; Scheckel, K.G.; Betts, A.R.; Smith, E. Predictive capabilities of in vitro assays for estimating Pb relative bioavailability in phosphate amended soils. Environ. Sci. Technol. 2016, 50, 13086-13094. [CrossRef] [PubMed]

32. Segre, C.; Leyarovska, N.; Chapman, L.; Lavender, W.; Plag, P.; King, A.; Kropf, A.; Bunker, B.; Kemner, K.; Dutta, P. The MRCAT insertion device beamline at the advanced photon source. In Proceedings of the Eleventh US National Conference Synchrotron Radiation Instrumentation, Stanford, CA, USA, 13-15 October 1999.

33. Kropf, A.; Katsoudas, J.; Chattopadhyay, S.; Shibata, T.; Lang, E.; Zyryanov, V.; Ravel, B.; McIvor, K.; Kemner, K.; Scheckel, K. The new MRCAT (Sector 10) bending magnet beamline at the advanced photon source. In Proceedings of the 10th International Conference on Radiation Instrumentation, Melbourne, Australia, 27 September-2 October 2009.

34. Davis, A.; Drexler, J.W.; Ruby, M.V.; Nicholson, A. Micromineralogy of mine wastes in relation to lead bioavailability, Butte, Montana. Environ. Sci. Technol. 1993, 27, 1415-1425. [CrossRef]

35. Alpers, C.N.; Rye, R.O.; Nordstrom, D.K.; White, L.D.; King, B. Chemical, crystallographic and stable isotopic properties of Alunite and Jarosite from acid-Hypersaline Australian lakes. Chem. Geol. 1992, 96, 203-226. [CrossRef]

36. Bigham, J.; Schwertmann, U.; Traina, S.; Winland, R.; Wolf, M. Schwertmannite and the chemical modeling of iron in acid sulfate waters. Geochim. Cosmochim. Acta 1996, 60, 2111-2121. [CrossRef]

37. Bothe, J.V.; Brown, P.W. Arsenic immobilization by calcium arsenate formation. Environ. Sci. Technol. 1999, 33, 3806-3811. [CrossRef]

38. Hongshao, Z.; Stanforth, R. Competitive adsorption of phosphate and arsenate on goethite. Environ. Sci. Technol. 2001, 35, 4753-4757. [CrossRef] [PubMed]

39. Jackson, B.P.; Miller, W. Effectiveness of phosphate and hydroxide for desorption of arsenic and selenium species from iron oxides. Soil Sci. Soc. Am. J. 2000, 64, 1616-1622. [CrossRef]

40. Manning, B.A.; Goldberg, S. Modeling competitive adsorption of arsenate with phosphate and molybdate on oxide minerals. Soil Sci. Soc. Am. J. 1996, 60, 121-131. [CrossRef]

41. Lindsay, W.L. Chemical Equilibria in Soils; John Wiley and Sons Ltd.: Hoboken, NJ, USA, 1979.

42. Zhang, J.; Stanforth, R. Slow adsorption reaction between arsenic species and goethite $(\alpha-\mathrm{FeOOH})$ : Diffusion or heterogeneous surface reaction control. Langmuir 2005, 21, 2895-2901. [CrossRef] [PubMed] 
43. Zhang, P.; Ryan, J.A. Formation of chloropyromorphite from galena ( $\mathrm{PbS}$ ) in the presence of hydroxyapatite. Environ. Sci. Technol. 1999, 33, 618-624. [CrossRef]

44. Burton, E.D.; Bush, R.T.; Sullivan, L.A.; Johnston, S.G.; Hocking, R.K. Mobility of arsenic and selected metals during re-flooding of iron-and organic-rich acid-sulfate soil. Chem. Geol. 2008, 253, 64-73. [CrossRef]

45. Garelick, H.; Jones, H.; Dybowska, A.; Valsami-Jones, E. Arsenic pollution sources. Rev. Environ. Contam. Toxicol. 2008, 197, 17-60. [PubMed]

46. Hansel, C.M.; Benner, S.G.; Fendorf, S. Competing Fe (II)-induced mineralization pathways of ferrihydrite. Environ. Sci. Technol. 2005, 39, 7147-7153. [CrossRef] [PubMed]

47. Burton, E.D.; Johnston, S.G.; Planer-Friedrich, B. Coupling of arsenic mobility to sulfur transformations during microbial sulfate reduction in the presence and absence of humic acid. Chem. Geol. 2013, 343, 12-24. [CrossRef]

48. Strawn, D.G.; Sparks, D.L. Effects of soil organic matter on the kinetics and mechanisms of Pb (II) sorption and desorption in soil. Soil Sci. Soc. Am. J. 2000, 64, 144-156. [CrossRef]

49. Kaštelan-Macan, M.; Petrovic, M. Competitive sorption of phosphate and marine humic substances on suspended particulate matter. Water Sci. Technol. 1995, 32, 349-355.

50. Zhou, S.; Song, Z.; Xu, M.; Chen, S. Effect of phosphate addition on mobility and phytoavailability of heavy metals in soils. In Phosphate in Soils: Interaction with Micronutrients. Radionuclides and Heavy Metals; CRC Press: Boca Raton, FL, USA, 2015; pp. 203-235.

51. Beak, D.G.; Basta, N.T.; Scheckel, K.G.; Traina, S.J. Bioaccessibility of lead sequestered to corundum and ferrihydrite in a simulated gastrointestinal system. J. Environ. Qual. 2006, 35, 2075-2083. [CrossRef] [PubMed]

52. Beak, D.G.; Basta, N.T.; Scheckel, K.G.; Traina, S.J. Linking solid phase speciation of Pb sequestered to birnessite to oral $\mathrm{Pb}$ bioaccessibility: Implications for soil remediation. Environ. Sci. Technol. 2007, 42, 779-785. [CrossRef]

53. Smith, E.; Weber, J.; Naidu, R.; McLaren, R.G.; Juhasz, A.L. Assessment of lead bioaccessibility in peri-urban contaminated soils. J. Hazard. Mater. 2011, 186, 300-305. [CrossRef] [PubMed]

54. Ying, S.C.; Kocar, B.D.; Fendorf, S. Oxidation and competitive retention of arsenic between iron-and manganese oxides. Geochim. Cosmochim. Acta 2012, 96, 294-303. [CrossRef]

55. Paktunc, D.; Majzlan, J.; Huang, A.; Thibault, Y.; Johnson, M.B.; White, M.A. Synthesis, characterization, and thermodynamics of arsenates forming in the Ca-Fe (III)-As (V)-NO3 system: Implications for the stability of Ca-Fe arsenates. Am. Mineral. 2015, 100, 1803-1820. [CrossRef]

56. Smedley, P.; Kinniburgh, D. A review of the source, behaviour and distribution of arsenic in natural waters. Appl. Geochem. 2002, 17, 517-568. [CrossRef]

57. Stollenwerk, K. Geochemical processes controlling transport of arsenic in groundwater: A review of adsorption. In Arsenic Ground Water; Springer: Boston, MA, USA, 2003; pp. 67-100.

58. Pierce, M.L.; Moore, C.B. Adsorption of Arsenite and Arsenate on Amorphous Iron Hydroxide. Water Res. 1982, 16, 1247-1253. [CrossRef]

59. Wang, S.; Terdkiatburana, T.; Tadé, M. Adsorption of $\mathrm{Cu}$ (II), $\mathrm{Pb}$ (II) and humic acid on natural zeolite tuff in single and binary systems. Sep. Purif. Technol. 2008, 62, 64-70. [CrossRef]

60. Baron, D.; Palmer, C.D. Solid-solution aqueous-solution reactions between jarosite $\left(\mathrm{KFe}_{3}\left(\mathrm{SO}_{4}\right)_{2}(\mathrm{OH})_{6}\right)$ and its chromate analog. Geochim. Cosmochim. Acta 2002, 66, 2841-2853. [CrossRef]

61. Kendall, M.R.; Madden, A.S.; Madden, M.E.E.; Hu, Q. Effects of arsenic incorporation on Jarosite dissolution rates and reaction products. Geochim. Cosmochim. Acta 2013, 112, 192-207. [CrossRef]

(C) 2018 by the authors. Licensee MDPI, Basel, Switzerland. This article is an open access article distributed under the terms and conditions of the Creative Commons Attribution (CC BY) license (http://creativecommons.org/licenses/by/4.0/). 